\title{
Investigation of ship-plume chemistry using a newly-developed photochemical/dynamic ship-plume model
}

\author{
H. S. Kim ${ }^{1}$, C. H. Song ${ }^{1}$, R. S. Park ${ }^{1}$, G. Huey ${ }^{2}$, and J. Y. Ryu ${ }^{3}$ \\ ${ }^{1}$ Dept. of Environmental Science and Engineering, Gwangju Institute of Science and Technology (GIST), Gwangju, Korea \\ ${ }^{2}$ School of the Earth and Atmospheric Sciences, Georgia Institute of Technology, Atlanta, Georgia, USA \\ ${ }^{3}$ Korea Environmental Industry and Technology Institute (KEITI), Seoul, Korea
}

Received: 14 April 2009 - Published in Atmos. Chem. Phys. Discuss.: 12 May 2009

Revised: 3 September 2009 - Accepted: 3 September 2009 - Published: 9 October 2009

\begin{abstract}
A photochemical/dynamic ship-plume model, which can consider the ship-plume dynamics and ship-plume chemistry, simultaneously, was developed to gain a better understanding of atmospheric impact of ship emissions. The model performance was then evaluated by a comparison with the observation data measured on a NOAA WP3D flight during the Intercontinental Transport and Chemical Transformation 2002 (ITCT 2K2) airborne field campaign. The simulation conditions and parameters, such as meteorological conditions, emission rates, and background gas and particulate species concentrations, were obtained directly and/or inferred indirectly from the ITCT $2 \mathrm{~K} 2$ observation data. The model-predicted concentrations showed good agreement with the observed concentrations of five ambient species $\left(\mathrm{NO}_{\mathrm{x}}, \mathrm{NO}_{\mathrm{y}}\right.$, ozone, $\mathrm{HNO}_{3}$, and $\left.\mathrm{H}_{2} \mathrm{SO}_{4}\right)$ at the eight plume transects by the WP-3D flight with strong correlations around the $1: 1$ line $(0.64 \leq R \leq 0.85)$. In addition, a set of tests were carried out to approximate the magnitude of the reaction probability of $\mathrm{HNO}_{3}$ onto sea-salt particles in the model-observation comparison framework. These results suggest that the reaction probability of $\mathrm{HNO}_{3}$ onto seasalt particles may be in the order of $0.05-0.1$. The equivalent $\mathrm{NO}_{\mathrm{x}}$ lifetime throughout the "entire plume" was also estimated from photochemical/dynamic ship-plume modeling. The $\mathrm{NO}_{\mathrm{x}}$ lifetimes estimated throughout the entire ship plume ranged from $2.64 \mathrm{~h}$ to $3.76 \mathrm{~h}$ under stable to neutral stability conditions. The short $\mathrm{NO}_{\mathrm{x}}$ lifetime over the entire ship plume clearly shows that the ship-plume chemistry shortens the $\mathrm{NO}_{\mathrm{x}}$ lifetime considerably. Therefore, the shipplume chemistry model should be used to model the changes in ship-plume chemical compositions and better evaluate the atmospheric impact of ocean-going ship emissions.
\end{abstract}

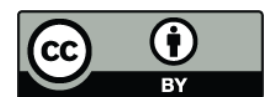

Correspondence to: C. H. Song (chsong@gist.ac.kr)

\section{Introduction}

Ocean-going ship emissions are considered important contributors to climate change and atmospheric environmental pollution in the marine boundary layer (MBL). This importance has been recognized since the late 1990s (Corbett and Fischbeck, 1997; Capaldo et al., 1999; Corbett et al., 1999; Lawrence and Crutzen, 1999). Corbett and Fischbeck (1997) and Corbett et al. (1999) first estimated the annual global emission fluxes of $\mathrm{SO}_{2}$ and $\mathrm{NO}_{\mathrm{x}}$ from oceangoing ships. They estimated that global $\mathrm{NO}_{\mathrm{x}}$ and $\mathrm{SO}_{2}$ emission fluxes in 1993 were $10.12\left(\mathrm{Tg} \mathrm{yr}^{-1}\right)$ and $8.48\left(\mathrm{Tg} \mathrm{yr}^{-1}\right)$, respectively. Since then, the $\mathrm{NO}_{\mathrm{x}}$ and $\mathrm{SO}_{2}$ emission fluxes from ocean-going ships have been further updated and reevaluated using more sophisticated ship-emission estimation methodologies and updated fuel combustion data (Endresen et al., 2003; Corbett and Koehler, 2003; Beirle et al., 2004). For example, Beirle et al. (2004) estimated the $\mathrm{NO}_{\mathrm{x}}$ emission fluxes from ocean-going ships over the Indian Ocean, using the GOME-derived $\mathrm{NO}_{2}$ vertical column density. Corbett and Koehler (2003) updated the global ship emission data using updated fuel consumption data for 2001. Based on Corbett and Koehler's estimation (2003), $\mathrm{NO}_{\mathrm{x}}$ and $\mathrm{SO}_{2}$ emissions contribute approximately $\sim 21 \%$ and $\sim 7 \%$ of the total global $\mathrm{NO}_{\mathrm{x}}$ and $\mathrm{SO}_{2}$ emissions from fuel combustion. Although ship $\mathrm{SO}_{2}$ emissions comprise $\sim 7 \%$ of the global $\mathrm{SO}_{2}$ emissions, it is a dominant source of $\mathrm{SO}_{2}$ within the MBL, and may produce significant amounts of non-sea-salt (nss) sulfate (Capaldo et al., 1999). The increased amount of nss-sulfate can further enhance the production of cloud condensation nuclei $(\mathrm{CCN})$ within the remote MBL, resulting in a negative global radiative forcing of $\sim-0.11 \mathrm{Wm}^{-2}$ (Capaldo et al., 1999; Phinney et al., 2009). Lawrence and Crutzen (1999) examined the perturbation effects of ocean-going ship-emitted $\mathrm{NO}_{\mathrm{x}}$ on the

Published by Copernicus Publications on behalf of the European Geosciences Union. 
oxidation cycles in the ship-going MBL. They found from a 3-D Eulerian Chemistry-Transport modeling (CTM) study that the ozone and $\mathrm{OH}$ radical concentrations were elevated by a factor of $\sim 2$ and $\sim 5$, respectively, when the oceangoing ship emissions were taken into account. However, their predictions overestimated the $\mathrm{NO}_{\mathrm{x}}$, ozone, and $\mathrm{OH}$ levels within the remote MBL (Kasibhatla et al., 2000; Davis et al., 2001; Song et al., 2003a; von Glasow et al., 2003). Several field observations also showed elevations of the ozone and $\mathrm{OH}$ levels in the MBL affected by ocean-going ship emissions (e.g., Davis et al., 2001; Chen et al., 2005). More recently, Endresen et al. (2003) estimated the global net radiative forcing from ship emissions using a global CTM (Oslo CTM2), and the net radiative forcing ranged from 0.01 to $0.02\left(\mathrm{~W} \mathrm{~m}^{-2}\right)$ but with considerable uncertainty. On the other hand, the emissions of particulate species from oceangoing ships can also affect the radiative forcing over ocean areas, with particles playing the important role of cloud condensation nuclei $(\mathrm{CCN})$ in the formation of marine stratiform clouds (Twomey, 1977; Radke et al., 1989; Ferek et al., 1998; Russell et al., 1999; Hudson et al., 2000), which are often called "ship tracks". Overall, $\mathrm{NO}_{\mathrm{x}}, \mathrm{SO}_{2}$, and particle emissions from ocean-going ships significantly affect the atmospheric oxidation cycles within the MBL and global radiation budget, even though there is still large uncertainty in their quantitative estimations.

As mentioned above, it was reported that the use of the coarse-grid 3-D CTMs in treating point-source emissions, such as ships, could lead to over-predictions in the $\mathrm{NO}_{\mathrm{x}}$, ozone, and OH levels (Kasibhatla et al., 2000; Davis et al., 2001; Song et al., 2003a; von Glasow et al., 2003; Chen et al., 2005), by skipping the nonlinear ship-plume chemistry. For example, Song et al. (2003a) focused on in-plume chemical transformations using a plume-chemistry model. Their study demonstrated the importance of taking the shipplume chemistry into account when determining the $\mathrm{NO}_{\mathrm{x}}$, ozone, and $\mathrm{OH}$ concentrations. von Glasow et al. (2003) also suggested that a failure to account for non-linear shipplume chemistry can result in over-predictions in the $\mathrm{NO}_{\mathrm{x}}$, ozone, and $\mathrm{OH}$ levels. However, these studies have limitations in that the model investigations were carried out based on a simple 0-dimensional Lagrangian photochemical box model without any model validation with observations. Although Chen et al. (2005) examined the ship-plume chemistry with plume observation data from the ITCT $2 \mathrm{~K} 2$ aircraft campaign and the predicted atmospheric concentrations from photo-stationary state modeling, their study may also have a limitation in that the model used in their study was not a full ship-plume chemistry model. Rather, it was a general photo-stationary state model constrained by the observed atmospheric species concentrations. Therefore, their model could not predict the concentrations over the "entire volume" of the ship plume.

The development of the entire volume ship-plume model is important because the ship-plume photochemistry is highly non-linear, not only along the plume-advecting direction (xdirection), but also in the plume-dispersing direction ( $y$ - and $\mathrm{z}$-directions). In addition, the distributions of the ship-plume species concentrations in the $\mathrm{y}$ - and z-directions are frequently "non-Gaussian", particularly for secondarily-formed species, such as ozone and $\mathrm{OH}$. The present study developed a photochemical/dynamic ship-plume model that can explicitly consider the non-linear and non-Gaussian characteristics of chemical evolution of the entire ship plume (Sect. 2). The data from the developed ship-plume photochemistry model was compared with aircraft observation data from the ITCT 2K2 campaign (Sect. 3). The developed photochemical/dynamic ship-plume model has many potential applications. Of these, three particular issues are discussed in the following three sections. Section 4 evaluates the magnitude of the reaction probability of $\mathrm{HNO}_{3}$ onto sea-salt particles $\left(\gamma_{\mathrm{HNO}_{3}, s s}\right)$ using the developed photochemical/dynamic ship-plume model, which is of considerable scientific interest. Section 5 estimates the $\mathrm{NO}_{\mathrm{x}}$ chemical lifetimes $\left(\tau_{\mathrm{NO}_{\mathrm{x}}}^{\mathrm{chem}}\right)$ over the entire ship plumes using the developed photochemistry/dynamics ship-plume model (Sect. 5). The accurate estimation of $\tau_{\mathrm{NO}_{\mathrm{x}}}^{\text {chem }}$ in the ship-plume is important, for example, when the $\mathrm{NO}_{\mathrm{x}}$ emission fluxes from ships are estimated from the satellite-retrieved $\mathrm{NO}_{2}$ columns over the ship-going oceans, as conducted by Beirle et al. (2004). Section 6 discusses the potential applications of the developed ship-plume model to a ship track study.

\section{Model development}

\subsection{Ship-plume chemistry}

In this study, we developed UBoM 2K8 model (Utility photochemical Box Model 2K8). Since the UBoM 2K8 model was first developed, it has been applied to three different types of atmospheric chemistry modeling study: (i) Lagrangian backward/forward trajectory photochemical modeling (Song et al., 2007), (ii) Eulerian photochemical box modeling, and (iii) ship-plume chemistry modeling (Song et al., 2003a, b). Although it has been operated in the three different modes, the three modes share the same atmospheric photochemical components, heterogeneous parameterizations and aerosol chemistry of the UBoM $2 \mathrm{~K} 8$ model.

The photochemical components of the UBoM $2 \mathrm{~K} 8$ model are the same as those used in previous studies (e.g., Crawford et al., 1999; Song et al., 2003a, b, 2007). The current model mechanism includes $71 \mathrm{H}_{\mathrm{x}} \mathrm{O}_{\mathrm{y}}-\mathrm{N}_{\mathrm{x}} \mathrm{O}_{\mathrm{y}}-\mathrm{CH}_{4}$ related reactions and 184 NMHC reactions. The former chemistry is based on Lurmann et al.'s (1986) condensed mechanism with some major modifications. These include appropriately updated rate coefficients as well as additional $\mathrm{NO}_{\mathrm{x}}$ and organic peroxide reactions (e.g., Atkinson et al., 1997; DeMore et al., 1997; Crawford et al., 1999). In addition to these gasphase photochemical reactions, several gas/aqueous-phase 
sulfur reactions/equilibria were also included to examine the chemical fates of the various sulfur species in the atmosphere (Song et al., 2003b). The gas-particle interactions between nitrate precursor species $\left(\mathrm{N}_{2} \mathrm{O}_{5}, \mathrm{NO}_{3}\right.$, and $\left.\mathrm{HNO}_{3}\right)$ and aerosols were considered using pseudo-first order kinetics:

$$
\frac{d\left[C_{i}\right]}{d t}=-k_{m t, i}\left[C_{i}\right]
$$

where $\left[C_{i}\right]$ is the concentration of gas-phase species $i$, and $k_{m t, i}$ is the overall mass transfer coefficient $\left(\mathrm{s}^{-1}\right)$. The Schwartz formula to calculate $k_{m t, i}$ for the precursor species of nitrate (Freiberg and Schwartz, 1981) was used:

$k_{m t, i}=\frac{\gamma_{i} S \overline{v_{i}}}{4}$

where $\gamma_{i}$ represents the reaction probability (or uptake coefficient) of the precursor species $i, S$ is the aerosol surface density $\left(\mathrm{cm}^{2} \mathrm{~cm}^{-3}\right)$, and $\overline{v_{i}}$ is the molecular mean velocity $\left(\mathrm{cm} \mathrm{s}^{-1}\right)$ of the precursor species $i$. In particular, using Eqs. (1) and (2), a parameterization for $\mathrm{HNO}_{3}$ partitioning onto atmospheric aerosols was added to the UBoM $2 \mathrm{~K} 8$ model, which had not been considered explicitly in previous studies (Song et al., 2003a, b, 2007; Chen et al., 2005).

In order to consider the interactions between sulfate precursor species $\left(\mathrm{SO}_{2}\right.$ and $\left.\mathrm{H}_{2} \mathrm{SO}_{4}\right)$ and sea-salt particles, the following parameterization was used to account for the accommodation and subsequent aqueous-phase oxidation reactions of $\mathrm{SO}_{2}$ in sea-salt particles (Brasseur et al., 1999; Mari et al., 1999; Song et al., 2003b):

$$
\frac{1}{k_{t, \mathrm{SO}_{2}}}=\frac{1}{k_{m t, \mathrm{SO}_{2}}}+\frac{1}{k_{\mathrm{O}_{3}}+k_{\mathrm{H}_{2} \mathrm{O}_{2}}}
$$

where $k_{t, \mathrm{SO}_{2}}$ represents the total (or net) $\mathrm{SO}_{2}$ scavenging and oxidation loss coefficient $\left(\mathrm{s}^{-1}\right)$; and $k_{\mathrm{O}_{3}}$ and $k_{\mathrm{H}_{2} \mathrm{O}_{2}}$ denote the overall oxidation rate coefficients $\left(\mathrm{s}^{-1}\right)$ by aqueous-phase ozone and $\mathrm{H}_{2} \mathrm{O}_{2}$, respectively. For the condensation of $\mathrm{SO}_{2}$ and $\mathrm{H}_{2} \mathrm{SO}_{4}, k_{m t, i}$ and $\gamma_{i}$ are replaced by $k_{t, i}$ and $\alpha_{i}$ (mass accommodation coefficient) in Eqs. (1) and (2), respectively. More details on the parameterizations can be found in the report by Song et al. (2003b).

The photolysis rate coefficients used are those based on a DISORT 4-stream implementation of the NCAR Tropospheric Ultraviolet-Visible (TUV) radiative code with an updated $\mathrm{O}\left({ }^{1} \mathrm{D}\right)$ quantum yield (Talukdar et al., 1997). The solutions to the ordinary differential equations that describe the time-dependent variations in atmospheric species concentrations were achieved using the Gear ODE (Ordinary Differential Equation) solver.

\subsection{Ship-plume dynamics}

The fundamentals of the plume transport and turbulent dispersion are based on Hanna et al. (1985)'s Offshore and
Coastal Dispersion (OCD) algorithm. The plume centerline concentration of species $i$ can be expressed as follows:

$$
\frac{C_{i}}{Q_{i}}=\frac{1}{\pi u_{r} \sigma_{y} \sigma_{z}}
$$

where $Q_{i}$ is the emission rate $\left(\mathrm{kg} \mathrm{s}^{-1}\right)$ of the primary pollutant species $i$ from the ship, $u_{r}$ is resulting wind speed, which is related to the relative motion of the ship and wind; and $\sigma_{y}$ and $\sigma_{z}$ represent the lateral and vertical turbulent dispersion parameters, respectively. Many meteorological variables are necessary to correctly determine $\sigma_{y}$ and $\sigma_{z}$, such as the standard deviations for the lateral and vertical fluctuation parameters, friction velocity $\left(u_{*}\right)$, and surface roughness length $\left(z_{o}\right)$. Previously, Song et al. (2003a) derived some useful expressions for $\sigma_{y}$ and $\sigma_{z}$ as a function of the downwind distance $(x)$ and atmospheric stability classes. These formulas (or methodology) were applied to the current study with some extensions. The extended formulas used in this study are shown in Table 1.

As mentioned previously, the basic concept of the newlydeveloped photochemical/dynamic ship-plume model is the same as that reported by Song et al. (2003a, b). Figure 1a shows a schematic diagram of the dynamic plume development due to turbulent dispersion. In the course of plume development, the plume is dispersed elliptically at the $\mathrm{y}-\mathrm{z}$ plane, as shown in Fig. 1a. In case that the boundary layer is capped by inversion at height $h$, it was assumed that the plumes cannot be dispersed above the mixing height. At this point, $\sigma_{z}$ is not allowed to expand beyond approximately $0.8 \mathrm{~h}$. Therefore, in this case, dispersion takes place only in the y-direction (refer to Fig. 1b). Based on this, the dilution factors for species $i\left(D_{i, k}\right)$ were defined using the following equations (Song et al., 2003a):

$$
\begin{array}{ll}
D_{i, k}=\frac{C_{i, k+1}}{C_{i, k}}=\frac{\left(\sigma_{y} \sigma_{z}\right)_{k}}{\left(\sigma_{y} \sigma_{z}\right)_{k+1}}, & \text { if } \sigma_{z} \leq 0.8 \mathrm{~h} \\
D_{i, k}=\frac{C_{i, k+1}}{C_{i, k}}=\frac{\left(\sigma_{y}\right)_{k}}{\left(\sigma_{y}\right)_{k+1}}, & \text { if } \sigma_{z}>0.8 \mathrm{~h}
\end{array}
$$

where $C_{i, k}$ and $C_{i, k+1}$ denote the concentration of species $i$ at the time steps $k$ and $k+1$, respectively (see Fig. 1a and b). The value of $D_{i, k}$ is always between 0 and 1 . This dilution factor can be understood as a ratio of the elliptical plume areas at the $\mathrm{y}-\mathrm{z}$ plane during $\Delta t$. Therefore, the change in concentration of species $i\left(\Delta C_{i}^{D}\right)$ due to atmospheric turbulent dispersion (or dilution) can be expressed by:

$$
\Delta C_{i}^{D}=C_{i, k+1}-C_{i, k}=\left(D_{i, k}-1\right) C_{i, k}+\left(1-D_{i, k}\right) C_{i, b}
$$

Here, $C_{i, b}$ indicates the background (out-plume) concentration of species $i$.

In order to predict the plume concentrations throughout the entire ship plume, it was assumed that the concentrations of primary pollutants, such as $\mathrm{NO}_{\mathrm{x}}$ and $\mathrm{SO}_{2}$, are distributed 
Table 1. Formulas for the later and vertical dispersion parameters, $\sigma_{\mathrm{y}}(x)$ and $\sigma_{z}(x)$, as a function of the downwind distance, $x(\mathrm{~m})$, over the ocean $^{1}$.

\begin{tabular}{lll}
\hline Pasquill stability class & $\sigma_{\mathrm{y}}(\mathrm{m})^{2}$ & $\sigma_{z}(\mathrm{~m})$ \\
\hline For $x<10 \mathrm{~km}$ & & \\
A & $0.11 x\left(u / u_{r}\right)\left(1+0.0001 x\left(u / u_{r}\right)\right)^{-1 / 2}$ & $0.10 x\left(u / u_{r}\right)$ \\
B & $0.08 x\left(u / u_{r}\right)\left(1+0.0001 x\left(u / u_{r}\right)\right)^{-1 / 2}$ & $0.06 x\left(u / u_{r}\right)$ \\
C & $0.055 x\left(u / u_{r}\right)\left(1+0.0001 x\left(u / u_{r}\right)\right)^{-1 / 2}$ & $0.04 x\left(u / u_{r}\right)\left(1+0.0002 x\left(u / u_{r}\right)\right)^{-1 / 2}$ \\
D & $0.04 x\left(u / u_{r}\right)\left(1+0.0001 x\left(u / u_{r}\right)\right)^{-1 / 2}$ & $0.03 x\left(u / u_{r}\right)\left(1+0.0015 x\left(u / u_{r}\right)\right)^{-1 / 2}$ \\
E & $0.03 x\left(u / u_{r}\right)\left(1+0.0001 x\left(u / u_{r}\right)\right)^{-1 / 2}$ & $0.015 x\left(u / u_{r}\right)\left(1+0.0003 x\left(u / u_{r}\right)\right)^{-1}$ \\
F & $0.02 x\left(u / u_{r}\right)\left(1+0.0001 x\left(u / u_{r}\right)\right)^{-1 / 2}$ & $0.008 x\left(u / u_{r}\right)\left(1+0.0003 x\left(u / u_{r}\right)\right)^{-1}$ \\
For $x>10 \mathrm{~km}$ & & \\
A & $0.11 x\left(u / u_{r}\right)\left(1+u / u_{r}\right)^{-1 / 2}$ & $0.10 x\left(u / u_{r}\right)$ \\
B & $0.08 x\left(u / u_{r}\right)\left(1+u / u_{r}\right)^{-1 / 2}$ & $0.06 x\left(u / u_{r}\right)$ \\
C & $0.055 x\left(u / u_{r}\right)\left(1+u / u_{r}\right)^{-1 / 2}$ & $0.04 x\left(u / u_{r}\right)\left(1+0.0002 x\left(u / u_{r}\right)\right)^{-1 / 2}$ \\
D & $0.04 x\left(u / u_{r}\right)\left(1+u / u_{r}\right)^{-1 / 2}$ & $0.03 x\left(u / u_{r}\right)\left(1+0.0015 x\left(u / u_{r}\right)\right)^{-1 / 2}$ \\
E & $0.03 x\left(u / u_{r}\right)\left(1+u / u_{r}\right)^{-1 / 2}$ & $0.015 x\left(u / u_{r}\right)\left(1+0.0003 x\left(u / u_{r}\right)\right)^{-1}$ \\
F & $0.02 x\left(u / u_{r}\right)\left(1+u / u_{r}\right)^{-1 / 2}$ & $0.008 x\left(u / u_{r}\right)\left(1+0.0003 x\left(u / u_{r}\right)\right)^{-1}$ \\
\hline
\end{tabular}

${ }^{1}$ Here, $u$ and $u_{r}$ represent the wind speed and resulting wind speed, respectively.

2 Because the standard deviation for lateral fluctuation in the turbulent velocity is not allowed to drop below $0.5 \mathrm{~m} \mathrm{~s}^{-1}$ (Hanna et al., 1985), the minimum value for $\sigma_{\mathrm{y}}$ is $0.5 / u$.

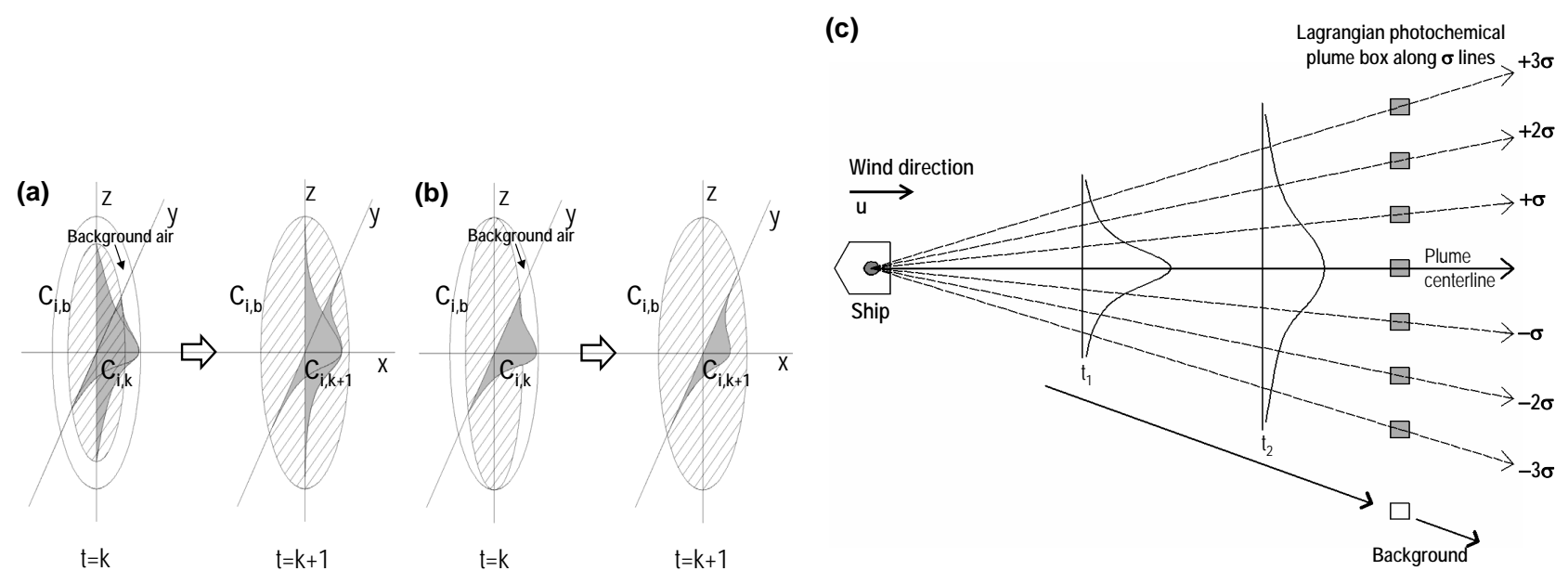

Fig. 1. Schematic diagram of ship-plume dispersion, (a) when $\sigma_{z}<0.8 \mathrm{~h}$ and (b) when $\sigma_{z}>0.8 \mathrm{~h}$. (c) The illustration is shown for multiple Lagrangian ship-plume photochemical box runs. The grey boxes represent the air parcels inside the ship plume, whereas the white box represents an air parcel outside the ship plume.

along the $y-z$ plane, with Gaussian shapes (refer to Fig. 1a and $b)$ :

$\xi(\chi, t)=\frac{1}{\sqrt{2 \pi} \sigma(t)} \exp \left[\frac{-\chi^{2}}{2 \sigma(t)^{2}}\right]$

where $\xi(\chi, t)$ represents the Gaussian function at plumetravel time $t$ and the location $\chi, \chi$ indicates the distance (deviation) from the plume center (i.e., $y=0$ and $z=0$ ) in the $\mathrm{y}$ and $\mathrm{z}$ directions, $\sigma(t)$ denotes the standard deviation (or dispersion parameter) at plume-travel time $t$, which was de- termined by the formulas in Table 1 . Hence, the primary pollutant distributions can be calculated from Eqs. (9) and (10):

$$
\begin{aligned}
& F_{c}(\chi, t)=\exp \left[\frac{-\chi^{2}}{2 \sigma(t)^{2}}\right] \\
& C_{i}(\chi, t)=C_{i, c l} F_{c}(\chi, t)
\end{aligned}
$$

where $F_{c}(\chi, t)$ is the frequency function, $C_{i}(\chi, t)$ is the concentration of the primary pollutant $i$ (such as $\mathrm{NO}_{\mathrm{x}}$ or 
$\mathrm{SO}_{2}$ ) in a given location $\chi$ at plume-travel time $t$, and $C_{i, c l}$ is the centerline concentration of species $i$ at plume-travel time $t$. From Eqs. (9) and (10), the peak (or centerline) concentrations of $\mathrm{NO}_{\mathrm{x}}$ and $\mathrm{SO}_{2}$ occur at $\chi=0$. The plume concentrations were calculated over the entire ship plume by running the multiple Lagrangian plume boxes along the different $\sigma$ lines, with $0.25 \sigma$ increments, as shown briefly in Fig. 1c. At the Lagrangian plume runs, the ship-plume chemistry is driven primarily by the primary pollutant concentrations, which were assumed to have Gaussian shapes. The levels of the secondary pollutants (e.g., ozone, $\mathrm{HNO}_{3}$, PAN, $\mathrm{NO}_{3}, \mathrm{~N}_{2} \mathrm{O}_{5}$, and $\mathrm{OH}$ ) were determined by both the ship-plume photochemistry and ship-plume dynamics, as described previously. The results from the multiple Lagrangian plume runs were smoothed on the $y$ - and z-planes at each time step. The model calculations were then forwarded toward the next calculation time step (i.e., time marching), until the ship plume had been diluted completely.

\subsection{Treatment of the background composition}

One more salient feature of the currently developed photochemical/dynamic ship-plume model is that it can consider the variations in the concentrations of background species. In this study, the model considered such effects by running a more box in the background air (refer to Fig. 1c). The time- and location-variant background concentrations were entrained into the ship-plume volume via a dilution process in the model, affecting the photochemical aging of the shipplume. Particularly, this modeling component allows for us to overcome the discontinuity problem that typically occurs at the interfaces between the edges of the ship-plume (say, $4 \sigma$ at the ship-plume cross-sections) and background air, when fixed background concentrations are used. For example, in the case where a fixed $\mathrm{HCHO}$ background concentration was used throughout the entire modeling period, large differences were found between the fixed $\mathrm{HCHO}$ background concentration and $\mathrm{HCHO}$ concentrations at the edge of the ship-plume. This is because the ship-plume (in-plume) HCHO concentrations at the plume edges vary with time, showing strong diurnal variations.

This modeling study can be distinguished from the work by Chen et al. (2005): (i) the model-predicted species concentrations in this study were not the solutions from a photostationary state approximation (i.e., $d c / d t=0$ ), and (ii) the model calculations were not made with any constraint with the observation data. Photo-stationary state approximations with the constraints of the observation data can produce satisfactory estimates for short-lived species at the locations where the observation data is available. However, it may not be able to provide adequate solutions for the long-lived and short-lived species concentrations at other ship-plume locations where the observation data are unavailable. In addition, it is difficult to constrain the photo-stationary state modeling with simultaneously observed plume concentrations at a given point of time because each atmospheric species measured inside the ship-plume by different instruments may have different (or independent) measurement time and resolutions. In contrast, in this study, a full ship-plume chemistry modeling was carried out with full time integration, starting only with the initial and background chemical and meteorological conditions and ship emission rate, as performed by Karamchandani et al. (2000) for a study of the Cumberland power plant plume during the Southern Oxidant Study (SOS).

\section{Model evaluations}

\subsection{Observations from ITCT $2 \mathrm{~K} 2$}

The simulation performance of the newly-developed photochemical/dynamic ship-plume model was evaluated by carrying out a comparison study using the observation data from the ITCT $2 \mathrm{~K} 2$ airborne field campaign. The ITCT $2 \mathrm{~K} 2$ shipplume experiment by the NOAA WP-3D aircraft was carried out approximately $\sim 100 \mathrm{~km}$ off the coast of California, around local noon time (17:40-21:30 GMT) on 8 May 2002 (refer to Fig. 2 regarding the location). Figure 2 also shows the sampling trajectory of the NOAA WP-3D flight. As shown in Fig. 2, the NOAA WP-3D traversed the ship plume eight times from transects A to H, (Chen et al., 2005). As also shown in Fig. 2, the NOAA WP-3D flight did not traverse the ship plume perpendicularly. The angle between the ship-plume travel and the WP-3D flight path was approximately $59^{\circ}$.

The simulation conditions and parameters, such as the meteorological conditions, emission rates, and background gas and particulate species concentrations, were obtained directly and/or inferred indirectly from the ITCT $2 \mathrm{~K} 2$ observation data. The wind velocity and direction were reported to be 9-11 $\left(\mathrm{m} \mathrm{s}^{-1}\right)$ and SSE, respectively. The ship was heading WNW, and its speed was $\sim 5 \mathrm{~m} \mathrm{~s}^{-1}$ ( $\sim 9.7$ knots) (Chen et al., 2005). During the WP-3D flight experiment, the sky was found to be clear (see Table 2). Here, the clear sky condition indicates no cloud venting out of the MBL, which was often reported (e.g., Ryerson et al., 1998; Sillman, 2000). Information on the sampling instruments was summarized in other publications (Brock et al., 2004; Nowak et al., 2004; Parrish et al., 2004; Chen et al., 2005).

\subsection{Determination of stability class and modeling conditions}

As discussed in Sect. 2.2 and shown in Table 1, the turbulent dispersion parameters, $\sigma_{y}$ and $\sigma_{z}$, are a strong function of the atmospheric stability. In this study, two independent meteorological datasets, (i) meteorological data measured by the NOAA WP-3D flight and (ii) NCEP 6 hourly reanalysis- 2 pressure-level data, were used to determine the 
Table 2. Simulation conditions used in this study.

\begin{tabular}{|c|c|}
\hline Variables & Values \\
\hline \multicolumn{2}{|l|}{ Emission rates } \\
\hline $\mathrm{NO}_{\mathrm{x}}(\mathrm{g} / \mathrm{s})$ & 6.25 \\
\hline $\mathrm{SO}_{2}(\mathrm{~g} / \mathrm{s})$ & 9.38 \\
\hline \multicolumn{2}{|l|}{ Meteorological conditions } \\
\hline Sky condition & Clear sky \\
\hline Stability class & Moderately stable (E), stable (F) \\
\hline Wind velocity $(\mathrm{m} / \mathrm{s})$ & $9-11$ \\
\hline Wind direction & SSE \\
\hline Mixing height $(\mathrm{m})^{1}$ & 800 \\
\hline \multicolumn{2}{|l|}{ Ship information } \\
\hline Latitude $\left({ }^{\circ} \mathrm{N}\right)$ & 36.19 \\
\hline Longitude $\left({ }^{\circ} \mathrm{W}\right)$ & 123.06 \\
\hline Moving direction & WNW \\
\hline Speed (knot) & 9.7 \\
\hline \multicolumn{2}{|l|}{ Aerosol-related variables } \\
\hline Background aerosol type & Sea-salt aerosols \\
\hline $\begin{array}{l}\text { Aerosol surface area } \\
\left(\mu \mathrm{m}^{2} / \mathrm{cm}^{3}\right)\end{array}$ & $90-120$ \\
\hline$\gamma \mathrm{N}_{2} \mathrm{O}_{5}$ & 0.1 \\
\hline$\gamma \mathrm{NO}_{3}$ & 0.01 \\
\hline$\gamma_{\mathrm{HNO}_{3}}{ }^{2}$ & 0.05 \\
\hline$\alpha_{\mathrm{SO}_{2}}{ }^{3}$ & 0.11 \\
\hline$\alpha_{\mathrm{H}_{2} \mathrm{SO}_{4}}{ }^{4}$ & 0.79 \\
\hline Aerosol $\mathrm{pH}^{5}$ & 6.9 \\
\hline \multicolumn{2}{|c|}{ Background concentrations (ppbv) ${ }^{6}$} \\
\hline$\left[\mathrm{NO}_{\mathrm{x}}\right]$ & 0.14 \\
\hline$\left[\mathrm{O}_{3}\right]$ & 40 \\
\hline [CO] & 130 \\
\hline$\left[\mathrm{SO}_{2}\right]$ & 0.4 \\
\hline$\left[\mathrm{C}_{3} \mathrm{H}_{8}\right]$ & 0.37 \\
\hline$\left[\mathrm{H}_{2} \mathrm{SO}_{4}\right]$ & 0.0004 \\
\hline$[P A N]^{7}$ & 0.135 \\
\hline
\end{tabular}

${ }^{1}$ Chen et al. (2005); ${ }^{2}$ sensitivity tests were made over the range of $\gamma_{\mathrm{HNO}_{3}}=10^{-2}-10^{-1}$ (refer to Sect. 4 in this manuscript); 3 Worsnop et al. (1989); ${ }^{4}$ Jefferson et al. (1997); ${ }^{5}$ assumed, based on Song et al. (2003b); ${ }^{6}$ obtained from WP-3D aircraft observations; also, refer to Chen et al. (2005); ${ }^{7}$ Chen et al. (2005).

stability classes of the MBL within which the NOAA WP3D ship-plume measurements had been taken. Figure 3a shows the vertical temperature profiles obtained from the WP-3D flight observations. The WP-3D aircraft measurements were carried out over a large ocean area of approximately $160 \mathrm{~km} \times 200 \mathrm{~km}$, as shown in Fig. 2 . Since the stability class should be determined within the MBL where the ship plume developed, the vertical temperature data is selected carefully at three locations where the flight intercepted the ship plume at different altitudes (i.e., around transects

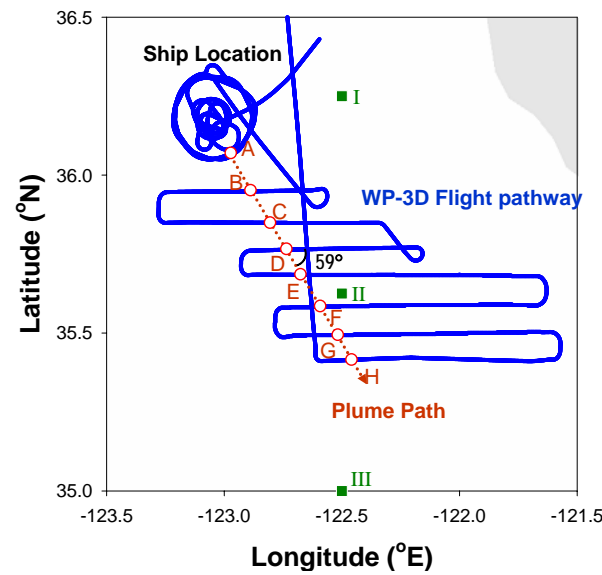

Fig. 2. Eight ship-plume transects $(\mathrm{A}-\mathrm{H})$ made by NOAA WP-3D flight near the California coast (Chen et al., 2005). I, II, and III denote three locations where the NCEP reanalysis data were obtained.

A, E and F, refer to Fig. 2). Based on the temperature profiles, the actual lapse rates of air temperature $\left(\Gamma ; \mathrm{K} \mathrm{km}^{-1}\right)$ were derived from the sea surface to $800 \mathrm{~m}$ a.s.l. The $\Gamma$ from the WP-3D aircraft observations ranged from $6.84\left(\mathrm{~K} \mathrm{~km}^{-1}\right)$ to $9.72\left(\mathrm{~K} \mathrm{~km}^{-1}\right)$. The atmospheric stability classes were then determined by a comparison of the actual lapse rate $(\Gamma)$ with the dry adiabatic lapse rates $\left(\Gamma_{d}\right) . \Gamma_{d}$ were reported approximately to be $\sim 10 \mathrm{~K} \mathrm{~km}^{-1}$ in an ideal atmosphere (Gill, 1982). If $\Gamma<\Gamma_{d}$, an air parcel that undergoes adiabatic displacement from its equilibrium level tends to return to its equilibrium level, and the atmosphere is said to be in statically stable or stably stratified (Holton, 1992). From this analysis, it was concluded that the most likely atmospheric stability within the MBL exists between moderately stable (E) and stable (F).

However, this conclusion contrasts with the one drawn by Chen et al. (2005). They reported that the likely stability class would be between unstable and neutral. Therefore, the stability class inferred from the meteorological data observed by the WP-3D aircraft in this study was confirmed once more with an independent dataset: NCEP 6 hourly reanalysis-2 pressure level data. Figure $3 \mathrm{~b}$ shows the temperature profiles over the three locations (I, II, and III). The three rectangular points in Fig. 2 (I, II, and III), represent the locations where the NECP 6 hourly reanalysis- 2 pressure-level data was obtained. The NCEP data obtained at 11 a.m. on 8 May 2002 (when the WP-3D aircraft began to measure the plume composition), were applied to this analysis. The values of $\Gamma$ from the NCEP reanalysis data were $0.92\left(\mathrm{~K} \mathrm{~km}^{-1}\right)$, $0.63\left(\mathrm{~K} \mathrm{~km}^{-1}\right)$, and $0.34\left(\mathrm{~K} \mathrm{~km}^{-1}\right)$ for the locations I, II, and III, respectively. The large difference between $\Gamma$ and $\Gamma_{d}$ strongly suggests that the likely stability class would be a stable $(F)$ condition. This indicates that the MBL examined in this study would not be under unstable or neutral conditions, as suggested by Chen et al. (2005). Therefore, 
photochemical/dynamic ship-plume model simulations were carried out with the two atmospheric stability classes: (1) moderately stable and (2) stable conditions.

The concentrations of gas-phase primary and secondary pollutants, such as $\mathrm{NO}, \mathrm{NO}_{2}, \mathrm{NO}_{\mathrm{y}}$, ozone, $\mathrm{CO}, \mathrm{CO}_{2}$, NMHCs, $\mathrm{SO}_{2}, \mathrm{HNO}_{3}, \mathrm{H}_{2} \mathrm{SO}_{4}$, were obtained from the NOAA WP-3D observations. The observed mean background concentrations of the gas-phase species outside the ship plume for $\mathrm{NO}_{\mathrm{x}}, \mathrm{SO}_{2}$, ozone, $\mathrm{CO}, \mathrm{H}_{2} \mathrm{SO}_{4}, \mathrm{HNO}_{3}$, PAN, and $\mathrm{C}_{3} \mathrm{H}_{8}$ were $\sim 140 \mathrm{pptv}, 400 \mathrm{pptv}, 40 \mathrm{ppbv}, 130 \mathrm{ppbv}$, $0.4 \mathrm{pptv}, 5 \mathrm{pptv}, 135 \mathrm{pptv}$, and $370 \mathrm{pptv}$, respectively. The aerosol-related variables, such as number, size, and volume concentrations, were measured directly using a combination of an aerosol size spectrometer and white light-scattering methods. The chemical composition of particulate species was measured using a particle-into-liquid sampler coupled with ion chromatographs (PILS-IC) (Weber et al., 2001; Orsini et al., 2003). Table 2 summarizes the background conditions. As mentioned in Sect. 2.3, the background HCHO and $\mathrm{HNO}_{3}$ concentrations were calculated from the background box shown in Fig. 1c.

In order to consider atmospheric heterogeneous processes, the values of the reaction probabilities $\left(\gamma_{i}\right)$ for $\mathrm{N}_{2} \mathrm{O}_{5}, \mathrm{NO}_{3}$, and $\mathrm{HNO}_{3}$, mass accommodation coefficients $\left(\alpha_{i}\right)$ for $\mathrm{SO}_{2}$ and $\mathrm{H}_{2} \mathrm{SO}_{4}$, and aerosol $\mathrm{pH}$, were obtained from previous reports (Song et al., 2003a, b), and are shown in Table 2. However, the reaction probability of $\mathrm{HNO}_{3}\left(\gamma_{\mathrm{HNO}_{3}, s s}\right)$ on sea-salt particles was assumed to be 0.05 . This study tests the magnitude of $\gamma_{\mathrm{HNO}_{3}, s s}$. The details will be discussed in Sect. 4. As indicated previously by Chen et al. (2005), the averaged surface density ( $S$ in Eq. 2 ) of sea-salt particles in the ship plume was estimated to be $90 \mu \mathrm{m}^{2} \mathrm{~cm}^{-3}$. Of a total of $120 \mu \mathrm{m}^{2} \mathrm{~cm}^{-3}$, the surface density of $30 \mu \mathrm{m}^{2} \mathrm{~cm}^{-3}$ was assumed to have originated from direct aerosol emissions from the ship. Therefore, these surface densities were used in Eqs. (1) and (2) to calculate the mass fluxes between the gas and particulate phases, respectively.

The emission rates were obtained directly from the observed emission factors to reduce the uncertainty in the estimation of the ship-emission rates. Because $\mathrm{CO}_{2}$ is the principal product, the $\mathrm{CO}_{2}$ balance could be a useful method for estimating the ship emission rate (Hobbs et al., 2000; Sinha et al., 2003). In general, the ideal reaction formula for complete oxidation in ship diesel powered-engines can be given by:

$\mathrm{C}_{x} \mathrm{H}_{y}+\left(x+\frac{y}{4}\right) \mathrm{O}_{2}=x \mathrm{CO}_{2}+\frac{y}{2} \mathrm{H}_{2} \mathrm{O}$

where the $\mathrm{y}$ to $\mathrm{x}$ ratio is 1.8 (Tuttle, 1955). From Reaction (R1), the mass ratio of $\mathrm{CO}_{2}$ to $\mathrm{C}_{\mathrm{x}} \mathrm{H}_{\mathrm{y}}$ is 3.2. Therefore, the mass flux of $\mathrm{CO}_{2}$ from fuel combustion is 3.2 times the fuel consumption rate. Chen et al. (2005) reported that the emission factors for $\mathrm{NO}_{\mathrm{x}}$ and $\mathrm{SO}_{2}$ in the ship experiment were $20 \pm 8(\mathrm{gN} / \mathrm{kg}$ fuel $)$ and $30 \pm 4\left(\mathrm{gSO}_{2} / \mathrm{kg}\right.$ fuel) from the ratios of $\Delta \mathrm{NO}_{\mathrm{x}} / \Delta \mathrm{CO}_{2}$, and $\Delta \mathrm{SO}_{2} / \Delta \mathrm{CO}_{2}$ with same mass
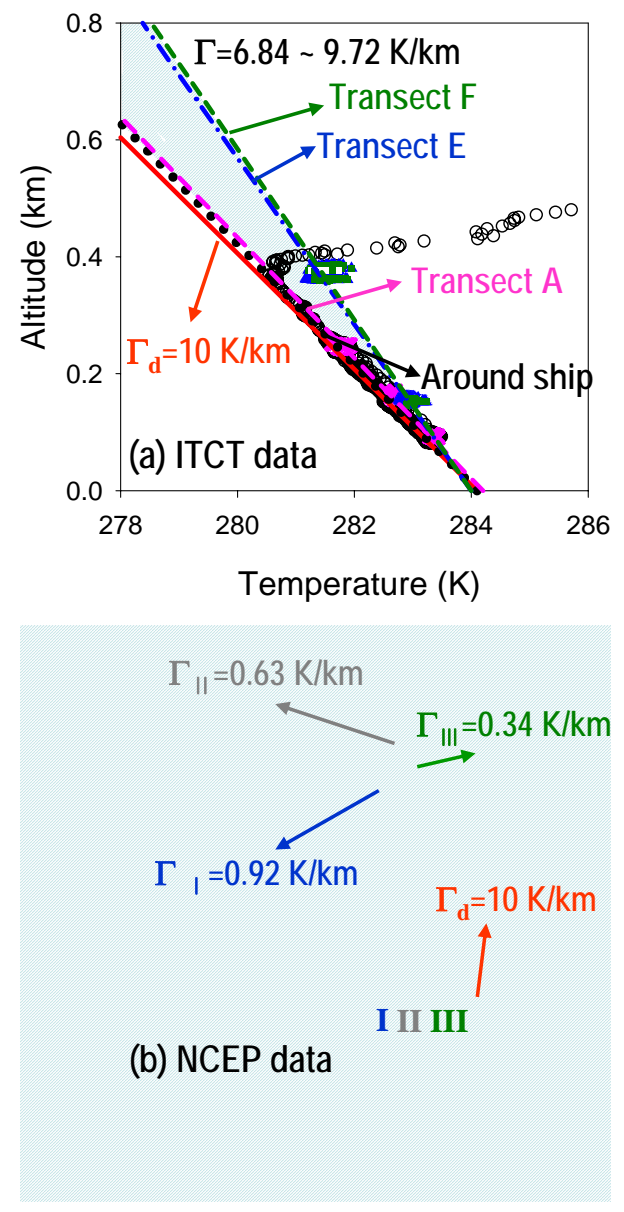

Fig. 3. Comparison between actual lapse rate $(\Gamma)$ and dry adiabatic lapse rate $\left(\Gamma_{d}\right)$ for the determination of stability class of the MBL (a) with observations measured by NOAA WP-3D flight and (b) with NCEP 6 hourly reanalysis-2 pressure level data.

balance (Hobbs et al., 2000; Sinha et al., 2003). The $\mathrm{NO}_{\mathrm{x}}$ and $\mathrm{SO}_{2}$ emission rates were calculated to be $6.25\left(\mathrm{~g} \mathrm{~s}^{-1}\right)$ and $9.38\left(\mathrm{~g} \mathrm{~s}^{-1}\right)$, respectively, based on the diesel-powered fuel consumption of a ship ( 27 ton day $\left.{ }^{-1}\right)$ (Table 2).

\subsection{Observations vs. model-predictions}

A comparison study was carried out using the ITCT $2 \mathrm{~K} 2$ aircraft observation data to evaluate the simulation performance of the newly-developed photochemical/dynamic shipplume model. As mentioned previously, the variables for the model simulations, such as emission rates, meteorological conditions, aerosol-related variables and background concentrations of the gas and particulate species, were obtained directly or inferred indirectly from the NOAA WP3D airborne observations. Among the observed atmospheric species, the concentrations of the five species, which include gas-phase primary and secondary pollutants $\left(\mathrm{NO}_{\mathrm{x}}\right.$, $\mathrm{NO}_{\mathrm{y}}$, ozone, $\mathrm{HNO}_{3}$, and $\mathrm{H}_{2} \mathrm{SO}_{4}$ ), were compared with the 
model-predicted concentrations. Only the five species concentrations were compared in this study, mainly due to the measurement response times of the atmospheric species. Since the WP-3D aircraft traversed the ship plume at very high speed $\left(\sim 360 \mathrm{~km} \mathrm{~h}^{-1}\right)$ and the plume widths were relatively narrow $(0.47-4.14 \mathrm{~km})$, each plume crossing occurred within approximately $1 \mathrm{~min}$. Only the five gas-phase species have sufficiently fast response times, whereas other species including particulate species have longer measurement response times. For example, the PILS-IC instrument has a measurement time resolution of $\sim 4 \mathrm{~min}$. Although $\mathrm{SO}_{2}$ has a fast measurement response time, it was excluded from this analysis. This is because the $\mathrm{SO}_{2}$ data measured by the aircraft were so scattered (very noisy) that it is difficult to distinguish the plume shape from the background at the eight shipplume transects, which was partly due to the detection limit of the instrument ( $350 \mathrm{pptv}$, refer to Brock et al., 2004). Because of the detection limit, the back ground values and many of the ship-plume enhancements could not be interpreted without averaging and some discussion (Brock et al., 2004). In addition, as mentioned previously, the WP-3D flight traversed the ship plume at an angle of approximately $59^{\circ}$. Therefore, for the purpose of comparison, the modelcalculated data was sampled along the eight cross sections.

Figure 4 shows the comparison results of $\mathrm{NO}_{\mathrm{x}}$ from transects A to H. As discussed in Sect. 3.2, the most likely atmospheric stability class of the MBL would be between moderately stable (E) and stable (F). Therefore, these two stability classes were chosen for the modeling conditions. As shown in Fig. $4 \mathrm{a}-\mathrm{h}$, the concentrations of $\mathrm{NO}_{\mathrm{x}}\left(\equiv \mathrm{NO}+\mathrm{NO}_{2}\right)$ decreased continuously due to turbulent dispersion (or dilution) and atmospheric photochemical transformation. As shown in Fig. 4, the newly-developed photochemical/dynamic shipplume model captures the observed concentrations reasonably well. As expected, the levels of $\mathrm{NO}_{\mathrm{x}}$ presented by the dashed lines (stable class F) were higher than those by the solid lines (moderately stable class E) due to less active turbulent dispersion in the stable class.

Although there was good agreement between observed and model-generated concentrations, there was a relatively large discrepancy in plume transects A and B. But, in the aged ship plumes, the differences between the observed and model-predicted concentrations decreased. Three possible causes for such discrepancies are: (1) effects of other ship emissions or polluted plumes; (2) uncertainties in the meteorological conditions/processes related to ship-plume dispersion and ship emissions rates; and (3) influence of air motion caused by aircraft movement during the measurement. When the ship plume is fresh, it is easy to distort the plume shape by the aircraft motion. As indicated in Fig. 2, the NOAA WP-3D flight spiraled clockwise near the ship location (particularly, between the ship location and transect A). The multiple circulations of the flight and turbulence caused by the WP-3D flight could distort the ship-plume shape and composition. However, the possible deformation effects of the

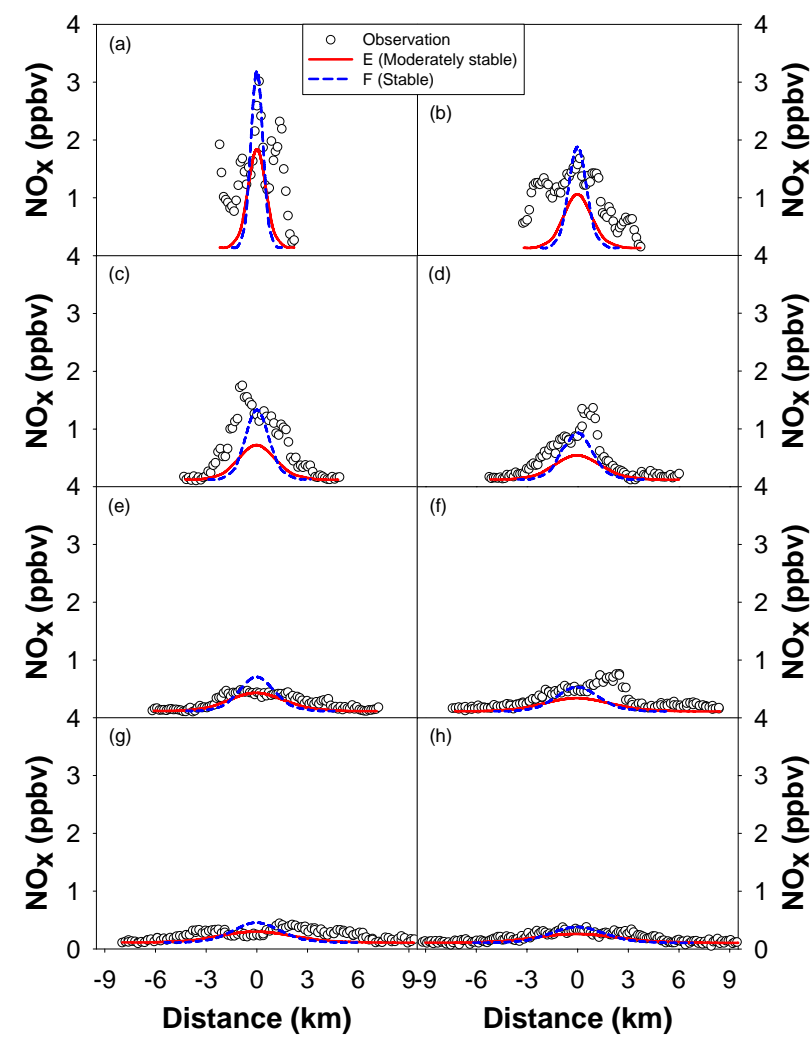

Fig. 4. Model-predicted vs. observed $\mathrm{NO}_{\mathrm{x}}$ concentrations across the eight ship-plume transects $(\mathrm{A}-\mathrm{H})$ under the stability classes of moderately stable (E) and stable (F). Panels $(\mathbf{a}-\mathbf{h})$ correspond to the comparison at the ship-plume transects $\mathrm{A}-\mathrm{H}$, sequentially.

ship-plume shape and concentrations decreased in the chemically aged and dispersed ship plumes. In addition, as suggested by Chen et al. (2005), the location of the ship experiment is a moderately polluted area. This was inferred by the fact that the background $\mathrm{NO}_{\mathrm{y}}$ (mostly, $\mathrm{NO}_{\mathrm{x}}$ ) concentrations close to the ship location were significantly larger than those in the downwind areas (Chen et al., 2005). As discussed in Sect. 2.2, the time- and location-variant background concentrations can be considered in the current model framework. However, further difficulties were encountered because the background volumes entrained into the ship-plume volume do not have uniform background concentrations, e.g. $\mathrm{NO}_{\mathrm{x}}$ and $\mathrm{NO}_{\mathrm{y}}$, particularly around the locations close to the ship due to the influences of other ships (or other sources). Some multi-peaks can be observed in panels a, b, and c in Figs. 4 and 5. Such peaks appear to be affected by the entrainment of the spotted elevations from background air. The current model framework cannot consider these situations (nor can other models), which may be a limitation to the current study. However, the discrepancies were reduced in the aged ship plume and the background composition is more uniform. There were additional uncertainties in the meteorological conditions/processes such as the stability class of the MBL and micro-meteorological mixing processes, and 
the emission rates of the primary pollutants from the ship. For example, the primary $\mathrm{HCHO}$ emission from the ship was not considered in this study. However, some studies have reported the importance of the primary $\mathrm{HCHO}$ emission from ships (e.g., Marbach et al., 2009). Also, near the ship locations, the composition of the fresh/young ship-plume can also be influenced by varied stability class. As indicated in Fig.3a, the recently-emitted, fresh ship-plume may experience a near neutral stability condition around transect A, where $\Gamma$ is almost equal to $\Gamma_{d}$. However, the current model did not consider this situation. Also, there is another possibility that the ship-plume composition can be influenced further by complicated micro-meteorological process that may not intrinsically follow the Gaussian shape. Overall, there remain large uncertainties in the analysis of the composition of the fresh ship-plumes near the ship location.

Figure 5 shows the model-predicted and observed $\mathrm{NO}_{\mathrm{y}}$ concentrations. Here, model-predicted $\mathrm{NO}_{\mathrm{y}}$ is defined as $\mathrm{NO}$ $+\mathrm{NO}_{2}+\mathrm{NO}_{3}+2 \mathrm{~N}_{2} \mathrm{O}_{5}+\mathrm{HNO}_{3}+\mathrm{HONO}+\mathrm{HNO}_{4}+\mathrm{PAN}$ $+\mathrm{NO}_{3}^{-}+$Organic nitrates. Again, there were relatively large discrepancies in the young ship plumes, but the discrepancies decreased in the photochemically-aged ship plumes. Because most of the $\mathrm{NO}_{\mathrm{y}}$ is occupied by $\mathrm{NO}_{\mathrm{x}}$, the differences between the observed and model-predicted $\mathrm{NO}_{\mathrm{y}}$ concentrations are similar to those of $\mathrm{NO}_{\mathrm{x}}$.

Figures 6-8 show the comparison results for secondary gas-phase pollutants: ozone, $\mathrm{HNO}_{3}$, and $\mathrm{H}_{2} \mathrm{SO}_{4}$. As shown in Fig. 6, the newly-developed photochemical/dynamic shipplume model captures the atmospheric ozone chemistry greatly. In the early plume development stages (Fig. 6a and b), the ozone levels are depleted below the background ozone level $(40 \mathrm{ppbv})$ at the plume centerline, whereas they appear to be produced at the edges of the ship plume. These "non-linear" changes in the ozone concentrations are caused by ozone titration and recovery processes at the ship-plume cross-section.

$\mathrm{NO}+\mathrm{O}_{3} \rightarrow \mathrm{NO}_{2}+\mathrm{O}_{2}$

$\mathrm{NO}_{2}+h v \rightarrow \mathrm{O}\left({ }^{3} \mathrm{P}\right)+\mathrm{NO}$

$\mathrm{O}\left({ }^{3} \mathrm{P}\right)+\mathrm{O}_{2} \stackrel{\mathrm{M}}{\rightarrow} \mathrm{O}_{3}$

When a ship emits a plume, ozone is titrated instantaneously by $\mathrm{NO}$ via Reaction (R2), because $95 \%$ of the $\mathrm{NO}_{\mathrm{x}}$ emitted from the ships is NO on a mass basis (Hewitt, 2001), and $\mathrm{NO}$ is also found in the excessive levels. At the beginning of the plume age, the ozone concentrations even decreased to almost 0 ppbv (Song et al., 2003a). After ozone titration, the ozone level was recovered by the photo-dissociation of $\mathrm{NO}_{2}$ (a temporary storage of ozone) and subsequent ozone formation process via Reactions (R3) and (R4) as well as by the entrainment of background ozone. As the ship plume develops, the levels of $\mathrm{NO}_{\mathrm{x}}$ drop, maintaining Gaussian shapes in the lateral and vertical ( $y-$ and $z-$ ) directions. Because of these Gaussian distributions, the edges of the ship plumes

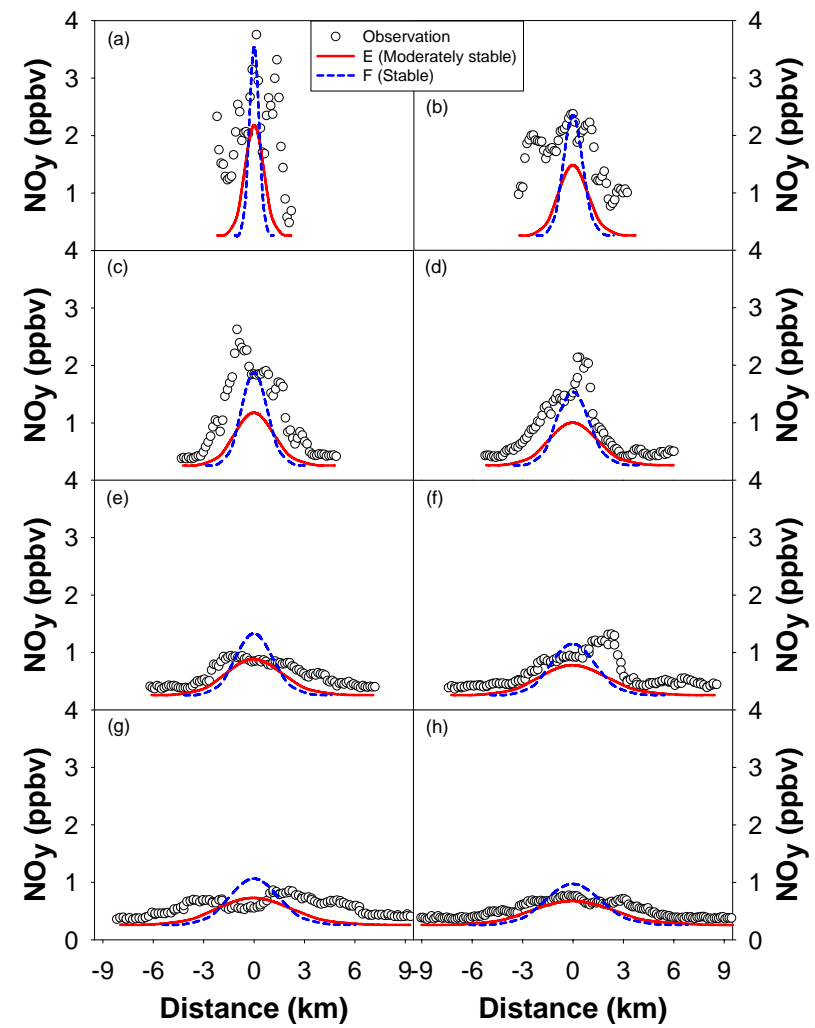

Fig. 5. As Fig. 4, except for $\mathrm{NO}_{\mathrm{y}}$.

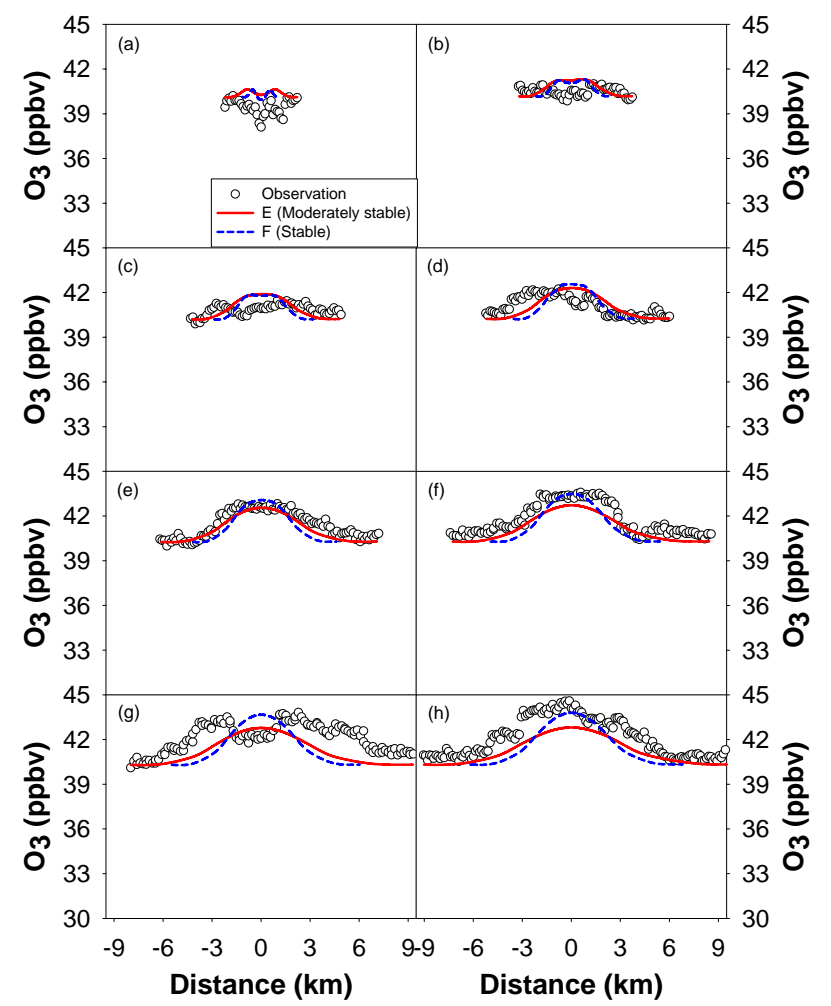

Fig. 6. As Fig. 4, except for ozone. 


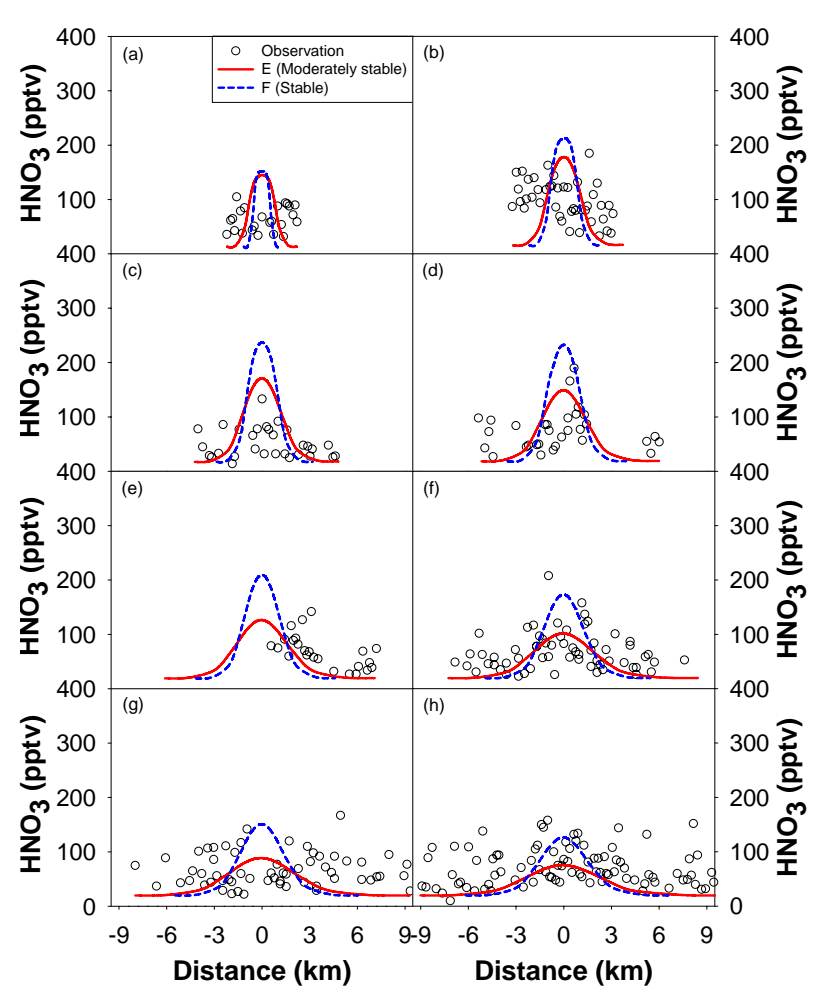

Fig. 7. As Fig. 4, except for $\mathrm{HNO}_{3} \cdot \gamma_{\mathrm{HNO}_{3}, \text { ss }}$ of 0.05 was used in this study.

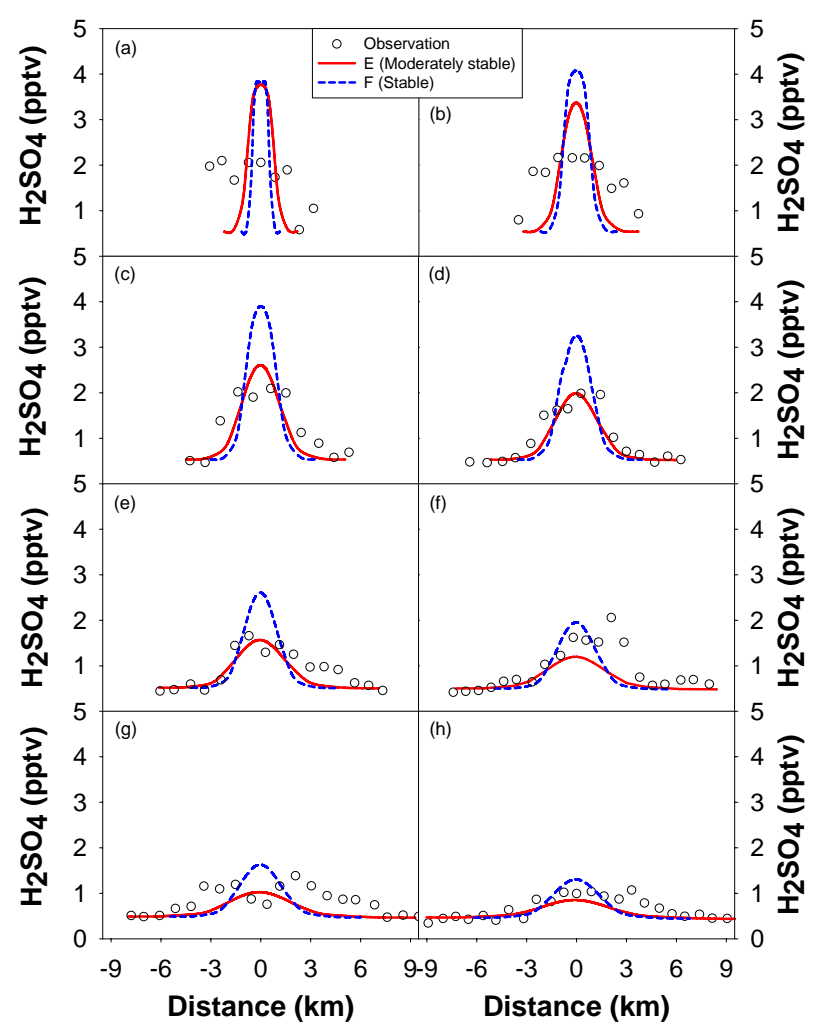

Fig. 8. As Fig. 4, except for $\mathrm{H}_{2} \mathrm{SO}_{4}$. first enter the ozone recovery stage (i.e., both Reactions (R3) and (R4) are active in this stage). However, the center of the plume is still in the ozone titration mode (i.e., Reaction R2 is dominant). As shown in Fig. 6a and b, this model can clearly capture these non-linear ozone titration-recovery characteristics over the ship-plume cross-sections. This again shows why the "entire ship-plume" model is necessary. Further analysis of the non-linear (and non-Gaussian) characteristics of the secondary pollutants, such as hydroxyl radicals $(\mathrm{OH})$, across the ship-plume cross sections will be reported in Sect. 5. After the early plume development stage, the entire plume enters the net ozone production mode. In Fig. 6c$\mathrm{h}$, the ozone concentrations were higher than the background ozone concentration of $40 \mathrm{ppbv}$ with Gaussian shapes across the ship-plume cross sections.

Figure 7 shows the observed and model-predicted $\mathrm{HNO}_{3}$ concentrations. Here, $\mathrm{HNO}_{3}$ concentrations were measured directly by Chemical Ionization Mass Spectrometer (CIMS) at $1 \mathrm{~Hz}$ (Huey and Lovejoy, 1996; Neuman et al., 2002). The observed $\mathrm{HNO}_{3}$ concentrations are highly scattered and do not show clear plume shapes (presumably, Gaussian) along the plume cross sections, as shown in Fig. 7 (see white circles in Fig. 7; it will also be shown in the latter part of this section that such high degree scattering cause large errors and biases in Table 3). The measurement precision of the CIMS instrument at low $\mathrm{HNO}_{3}$ levels was estimated at \pm 25 pptv. Therefore, the measurement data were selected with the consideration of the measurement precision in Fig. 7 (Neuman et al., 2002; Nowak et al., 2004).

In the ship-plume chemistry modeling, the modelpredicted $\mathrm{HNO}_{3}$ concentrations were determined by changing two governing factors: (1) stability classes ( $\mathrm{E}$ and $\mathrm{F}$ ) and (2) reaction probability of $\mathrm{HNO}_{3}$ into sea-salt particles $\left(\gamma_{\mathrm{HNO}_{3}, s s}\right)$. In Fig. 7 , the value of $\gamma_{\mathrm{HNO}_{3}, s s}$ was assumed to be 0.05 (the relaxation of $\gamma_{\mathrm{HNO}_{3}, s s}$ will be discussed further in Sect. 4). As shown in Fig. 7a-h, the model-predicted $\mathrm{HNO}_{3}$ concentrations appear to capture the approximate levels of observed $\mathrm{HNO}_{3}$ across the ship-plume cross section with $\gamma_{\mathrm{HNO}_{3}, s s}=0.05$. However, it should be noted that the measured $\mathrm{HNO}_{3}$ concentrations show considerable variations.

The atmospheric levels of $\mathrm{HNO}_{3}$ are controlled by $\mathrm{HNO}_{3}$ production and destruction processes. The major atmospheric production and destruction processes of $\mathrm{HNO}_{3}$ in the MBL are believed to take place via the following reactions:

$$
\begin{aligned}
& \mathrm{NO}_{2}+\mathrm{OH} \stackrel{\mathrm{M}}{\rightarrow} \mathrm{HNO}_{3} \\
& \mathrm{NO}_{3}+\mathrm{DMS} \rightarrow \mathrm{HNO}_{3}+\text { products } \\
& \mathrm{HNO}_{3}+\mathrm{NaCl} \stackrel{\text { hetero }}{\longrightarrow} \mathrm{NaNO}_{3}+\mathrm{HCl}
\end{aligned}
$$

where DMS in Reaction (R6) represents dimethylsulfide, and Reaction (R7) represents the heterogeneous conversion of $\mathrm{HNO}_{3}$ into particulate nitrate $\left(\mathrm{NO}_{3}^{-}\right)$, which could be associated preferably with $\mathrm{Na}^{+}$inside the sea-salt particles. 
As discussed in Sect. 2.1, this heterogeneous conversion of gas-phase $\mathrm{HNO}_{3}$ was parameterized, using Schwartz kinetics with $\gamma_{\mathrm{HNO}_{3}, s s}=0.05$ in Fig. 7.

Figure 8 shows the observed and model-predicted $\mathrm{H}_{2} \mathrm{SO}_{4}$ concentrations. Although the comparison results between the observed and model-predicted $\mathrm{H}_{2} \mathrm{SO}_{4}$ levels show reasonable agreement with each other (Fig. 8), the modelpredicted $\mathrm{H}_{2} \mathrm{SO}_{4}$ concentrations were more or less higher than the observed values, particularly in the young ship plumes, as shown in Fig. 8a-c. Similar positive biases (i.e., model-predicted concentrations $>$ observed concentrations) were also found in the $\mathrm{HNO}_{3}$ analysis in Fig. 7 (also refer to Fig. 9 and Table 3). Both overestimations in the $\mathrm{HNO}_{3}$ and $\mathrm{H}_{2} \mathrm{SO}_{4}$ concentrations can be explained partly by the possible over-predictions of the $\mathrm{OH}$ radical concentrations in the ship-plume model. In this sense, the over-predictions of the $\mathrm{HNO}_{3}$ and $\mathrm{H}_{2} \mathrm{SO}_{4}$ concentrations at transects $\mathrm{A}$ to $\mathrm{C}$ appear to be consistent. However, more detailed atmospheric species information, such as the $\mathrm{OH}$ radical and sulfate/nitrate concentrations, will be needed to more accurately investigate the cause of the over-predictions in the $\mathrm{HNO}_{3}$ and $\mathrm{H}_{2} \mathrm{SO}_{4}$ concentrations. Unfortunately, the ITCT WP-3D flight $\mathrm{OH}$ and sulfate/nitrate measurements did not have sufficiently fast time resolution inside the ship plume, as mentioned previously. However, the agreements between the observed and model-predicted $\mathrm{H}_{2} \mathrm{SO}_{4}$ concentrations again improve in the photochemically-aged ship plumes.

Figure 9 shows scatter plots of the model-predicted and flight-observed species concentrations. As discussed previously, the comparisons between the predicted and observed concentrations of the five species show good correlations around the 1:1 line. As shown in Fig. 9a-e, the correlation coefficients $(R)$ with the "moderately stable" and "stable" conditions range from 0.72 to 0.85 , and from 0.64 to 0.83 , respectively (except for $\mathrm{HNO}_{3}$ ). For further statistical investigations, the following four statistical parameters were introduced for error and bias analyses: (1) Root Mean Square Error (RMSE; absolute error), (2) Mean Normalized Gross Error (MNGE; relative error), (3) Mean Bias (MB; absolute bias), and (4) Mean Normalized Bias (MNB; relative bias).

$$
\begin{aligned}
& \text { RMSE }=\sqrt{\frac{1}{N} \sum_{1}^{N}\left(C_{i, \text { Model }}-C_{i, \text { Obs }}\right)^{2}} \\
& \text { MNGE }=\frac{1}{N} \sum_{1}^{N}\left(\frac{\left|C_{i, \text { Model }}-C_{i, \text { Obs }}\right|}{C_{i, \text { Model }}}\right) \times 100 \\
& \mathrm{MB}=\frac{1}{N} \sum_{1}^{N}\left(C_{i, \text { Model }}-C_{i, \text { Obs }}\right)
\end{aligned}
$$
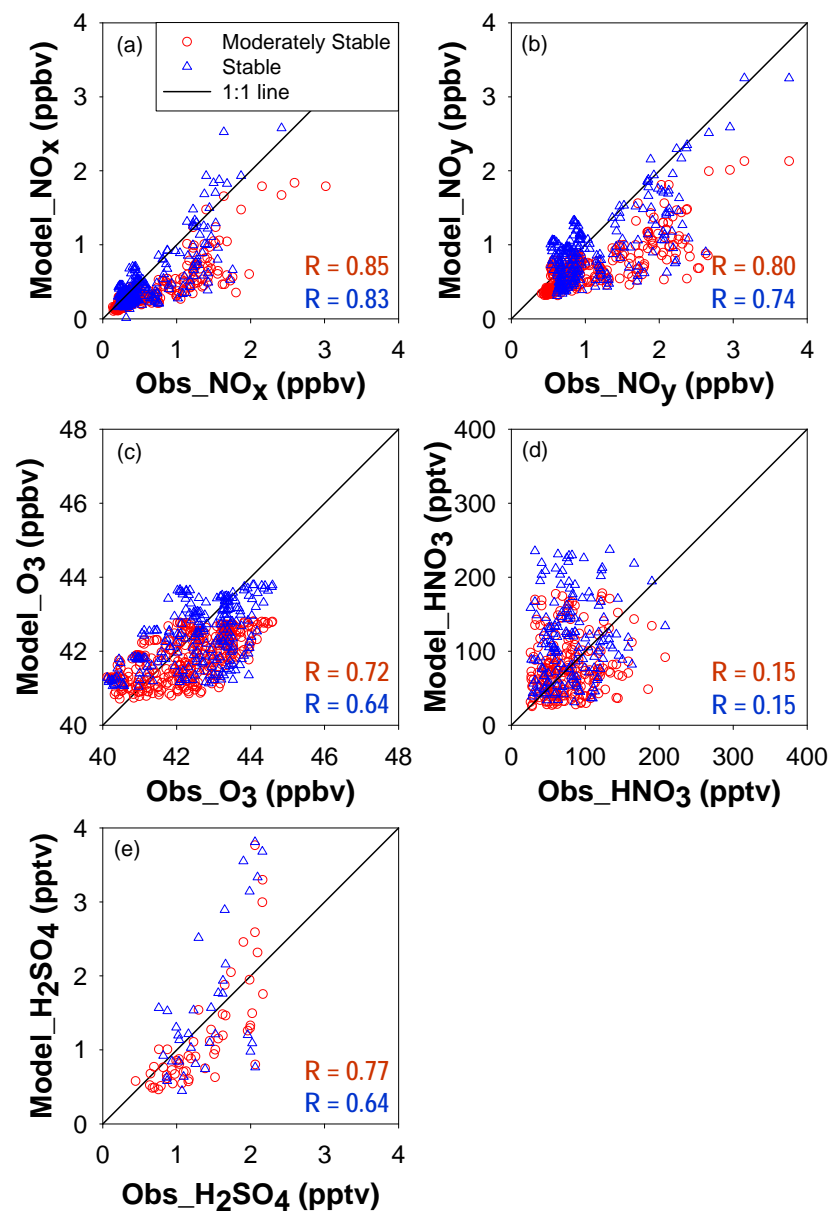

Fig. 9. Scatter plots of observed and model-predicted ship-plume concentrations: (a) $\mathrm{NO}_{\mathrm{x}}$; (b) $\mathrm{NO}_{\mathrm{y}}$; (c) ozone; (d) $\mathrm{HNO}_{3}$; (e) $\mathrm{H}_{2} \mathrm{SO}_{4}$. The red circles and blue triangles represent the concentrations predicted by the photochemical/dynamic ship-plume model under moderately stable and stable conditions, respectively.

$\mathrm{MNB}=\frac{1}{N} \sum_{1}^{N}\left(\frac{C_{i, \text { Model }}-C_{i, \mathrm{Obs}}}{C_{i, \mathrm{Obs}}}\right) \times 100$

where $C_{i}$,Model and $C_{i}$,Obs denote the model-predicted and observed concentrations of atmospheric species $i$, respectively. The statistical analyses were carried out with the species concentrations within $\pm 2 \sigma$ of the ship-plume distributions at the eight transects. The results are summarized in Table 3. The negative values in MBs and MNBs originated from the higher values of the observed $\mathrm{NO}_{\mathrm{x}}$ and $\mathrm{NO}_{\mathrm{y}}$ in the chemically young/fresh ship plumes. In contrast, the positive MBs and MNBs values for $\mathrm{HNO}_{3}$ and $\mathrm{H}_{2} \mathrm{SO}_{4}$ were discussed previously. It should be noted that the large $\mathrm{MB}$ and $\mathrm{MNBs}$ for $\mathrm{HNO}_{3}$ were caused by the large variations in the observed $\mathrm{HNO}_{3}$ concentrations. 
Table 3. Statistical analysis with observed and model-predicted plume concentrations at eight transects.

\begin{tabular}{lrrrrrrrr}
\hline Species & \multicolumn{3}{c}{ Moderately Stable (E) } & \multicolumn{4}{c}{ Stable (F) } \\
& RMSE $^{1}$ & MNGE & \multicolumn{1}{c}{ MB $^{1}$} & \multicolumn{1}{c}{ MNB $^{2}$} & RMSE $^{1}$ & MNGE $^{2}$ & MB $^{1}$ & MNB $^{2}$ \\
\hline $\mathrm{NO}_{\mathrm{x}}$ & 0.34 & 53.32 & -0.20 & -23.79 & 0.29 & 48.91 & -0.09 & -6.32 \\
$\mathrm{NO}_{\mathrm{y}}$ & 0.51 & 54.79 & -0.32 & -23.43 & 0.43 & 37.42 & -0.11 & -1.43 \\
$\mathrm{O}_{3}$ & 0.92 & 1.90 & -0.29 & -0.63 & 0.93 & 1.82 & -0.09 & -0.16 \\
$\mathrm{HNO}_{3}{ }^{3}$ & 47.56 & 54.84 & 2.00 & 21.98 & 69.91 & 46.42 & 35.00 & 69.45 \\
$\mathrm{H}_{2} \mathrm{SO}_{4}{ }^{3}$ & 0.52 & 30.75 & 0.00 & 4.78 & 0.79 & 38.56 & 0.25 & 15.63 \\
\hline
\end{tabular}

${ }^{1}$ Units are in ppbv, except for $\mathrm{HNO}_{3}$ and $\mathrm{H}_{2} \mathrm{SO}_{4} ;{ }^{2}$ units are in $\% ;{ }^{3}$ for $\mathrm{HNO}_{3}$ and $\mathrm{H}_{2} \mathrm{SO}_{4}$, the units for RMSE and MB are in pptv.

\section{Reaction probability of $\mathrm{HNO}_{3}$ into sea-saltparticles}

In Sect. 3, the overall model performances were tested by a comparison with the ITCT $2 \mathrm{~K} 2$ aircraft observation data. With this comparison framework, an attempt was made to evaluate the magnitude of $\gamma_{\mathrm{HNO}_{3}, s s}$. For this evaluation, sensitivity runs were carried out. The magnitude of $\gamma_{\mathrm{HNO}_{3}, s s}$ has been investigated in many laboratory experiments (e.g., Fenter et al., 1994; Laux et al., 1994; Abbatt and Waschewsky, 1998; Davies and Cox, 1998; Guimbud et al., 2002; Ghosal and Hemminger, 2004; Tolocka et al., 2004; Saul et al., 2006; Liu et al., 2007). However, as shown in Table $4, \gamma_{\mathrm{HNO}_{3}, s s}$ ranges widely from $\sim 10^{-1}$ to $\sim 10^{-4}$. For example, Abbatt and Waschewsky (1998) reported $\gamma_{\mathrm{HNO}_{3}, s s}$ to be $>0.2$, whereas other groups reported $\gamma_{\mathrm{HNO}_{3}, s s}$ to be $\sim 10^{-4}$ (e.g., Laux et al., 1994; Davies and Cox, 1998). There appears to be large uncertainty in the magnitude of $\gamma_{\mathrm{HNO}_{3}, s s}$. Therefore, it is believed that a determination of magnitude of $\gamma_{\mathrm{HNO}_{3}, s s}$ using "field-observation data" is imperative.

Based on the values shown in Table 4, the values of $\gamma_{\mathrm{HNO}_{3}, \text { ss }}$ were relaxed between $10^{-4}$ and $10^{-1}$ in this model sensitivity study. Figure 10 show the results of the sensitivity runs for the determination of magnitude of $\gamma_{\mathrm{HNO}_{3}, s s}$. Among the results, this paper presents the data from three sensitivity model runs with $\gamma_{\mathrm{HNO}_{3}, s s}=10^{-2}, 0.5 \times 10^{-1}$, and $10^{-1}$ in Fig. 10, because these model sensitivity runs show the best comparison results. If $\gamma_{\mathrm{HNO}_{3}, s s}=10^{-2}$ is used, the observed $\mathrm{HNO}_{3}$ concentrations become smaller than the modelpredicted $\mathrm{HNO}_{3}$ concentrations. However, the discrepancies between the model-predicted and observed $\mathrm{HNO}_{3}$ concentrations decreased as $\gamma_{\mathrm{HNO}_{3}, \text { ss }}$ was increased to $0.5 \times 10^{-1}$ and $10^{-1}$ (see the second and third columns in Fig. 10).

Based on these comparisons, it was concluded that the magnitude of $\gamma_{\mathrm{HNO}_{3}, \text { ss }}$ might be between $0.5 \times 10^{-1}$ and $10^{-1}$, which is consistent with the values estimated by Chen et al. (2005). However, there is still some uncertainty in this study. For example, Schwartz kinetics (Eq. 2) normally generates larger mass transfer coefficients than other kinetic models (e.g., Fuchs-Sutugin kinetics). The heterogeneous mass transfer rates between gas and particles are proportional to the second moment for particles in the kinetic regime (say, $K n>10$; here, $K n$ denotes the Knudsen number), whereas they are proportional to the first moment for particles in the continuum regime $(K n<0.1)$. Sea-salt particles are in the transitional regime $(0.1<K n<10)$ but can be closer to continuous regime particles (i.e., mostly coarsemode particles). However, Schwartz kinetics were used in this study because the separated aerosol distributions for the sea-salt particles were unavailable (i.e., it was impossible to separate the sea-salt size-distribution from the aerosol-size distribution measurements). The difference between the two approaches would be 2- or 3-fold, not an order of magnitude. In addition, as mentioned previously, there is uncertainty in the $\mathrm{HNO}_{3}$ production rates because it is unclear if the $\mathrm{OH}$ radical concentrations were predicted accurately by photochemical/dynamic ship-plume modeling. Overall, further studies on the issue of $\gamma_{\mathrm{HNO}_{3}, s s}$ will be necessary.

Here, another issue that can be raised is the role of ammonia $\left(\mathrm{NH}_{3}\right)$ in the heterogeneous conversion of $\mathrm{HNO}_{3}$. In a typical urban atmosphere, $\mathrm{HNO}_{3}$ partitioning into "acidic" urban particles tends to accompany $\mathrm{NH}_{3}$ condensation (Seinfeld and Pandis, 1998):

$\mathrm{HNO}_{3}+\mathrm{NH}_{3} \leftrightarrow \mathrm{NH}_{4} \mathrm{NO}_{3}$

$\mathrm{NH}_{3}$ condensation imparts alkalinity to acidic urban particles for the $\mathrm{HNO}_{3}$ partitioning (Seinfeld and Pandis, 1998; Song and Carmichael, 1999, 2001). However, in the case of alkaline aerosols, such as sea-salt and mineral dust, there is already sufficient alkalinity inside the particles, so that accompanying $\mathrm{NH}_{3}$ condensation is not necessary. On the other hand, although $\mathrm{HNO}_{3}$ partitioning accompanies $\mathrm{NH}_{3}$ condensation, $\mathrm{NH}_{3}$ would be vaporize immediately because partitioned $\mathrm{NO}_{3}^{-}$thermodynamically favors an association with $\mathrm{Na}^{+}$or other inorganic cations inside the sea-salt particles rather than with $\mathrm{NH}_{4}^{+}$(refer to Reaction R4; Song and Carmichael, 1999; Song et al., 2005). 
Table 4. Uptake coefficients of $\mathrm{HNO}_{3}$ (g) onto $\mathrm{NaCl}$ and sea-salt particles.

\begin{tabular}{|c|c|c|c|c|c|}
\hline Type of aerosol & $\begin{array}{c}\text { Uptake coefficient, } \\
\qquad \gamma_{\mathrm{HNO}_{3}}\end{array}$ & $\begin{array}{l}D_{p}^{1} \\
(\mu \mathrm{m})\end{array}$ & $\begin{array}{l}\mathrm{RH} \\
(\%)\end{array}$ & $\begin{array}{l}\text { Experimental } \\
\text { technique }\end{array}$ & Reference \\
\hline $\mathrm{NaCl}, \mathrm{NaBr}, \mathrm{KCl}$, and $\mathrm{KBr}$ & $(2.8 \pm 0.3) \times 10^{-2}$ & - & - & $\mathrm{QMA}^{2}$ & Fenter et al. (1994) \\
\hline $\mathrm{NaCl}$ & $(4 \pm 2) \times 10^{-4}$ & - & - & $\mathrm{XPS}^{3}$ & Laux et al. (1994) \\
\hline $\mathrm{NaCl}$ & $>0.2$ & $2-4$ & 75 & CIMS $^{4}$ & Abbatt and Waschewsky (1998) \\
\hline $\mathrm{NaCl}$ & $(0.28-1.10) \times 10^{-4}$ & - & 75 & Mass spectrometer & Davies and Cox (1998) \\
\hline Sea-salt & $0.5 \pm 0.2$ & $\sim 0.07$ & 55 & $\mathrm{~N}^{13}$ isotope tracer & Guimbaud et al. (2002) \\
\hline $\mathrm{NaCl}$ & $(5.25 \pm 3) \times 10^{-3}$ & $1-10$ & - & XPS & Ghosal and Hemminger (2004) \\
\hline $\mathrm{NaCl}$ & $(0.49-12.0) \times 10^{-3}$ & $0.11-0.22$ & 80 & SPMS $^{5}$ & Tolocka et al. (2004) \\
\hline $\mathrm{NaCl}$ and $\mathrm{NaCl} / \mathrm{MgCl}_{2}$ & $(0.23-1.26) \times 10^{-1}$ & $0.10-0.233$ & $10-85$ & SPMS & Saul et al. (2006) \\
\hline $\begin{array}{l}\mathrm{NaCl}, \mathrm{NaCl} / \mathrm{MgCl}_{2} \text {, } \\
\text { and Sea-salt }\end{array}$ & $\sim 0.02$ & $1.1-3.4$ & $20-80$ & CCSEM/EDX 6 & Liu et al. (2007) \\
\hline
\end{tabular}

${ }^{1} D_{p}$ represents the aerodynamic diameter of a particle; ${ }^{2}$ Quandrupole Mass Analyzer; ${ }^{3}$ X-ray Photoelectron Spectroscopy; ${ }^{4}$ Chemical Ionization Mass Spectrometer; ${ }^{5}$ Single Particle Mass Spectrometer; ${ }^{6}$ Computer-controlled Scanning Electron Microscopy coupled with Energy-dispersed X-ray.

\section{$5 \mathrm{NO}_{\mathrm{x}}$ chemical lifetimes}

A convenient way of examining the chemical evolution of pollution plumes is to quantify the $\mathrm{NO}_{\mathrm{x}}$ chemical lifetimes. Several research groups (e.g., Sillman et al., 1990; Karamchandani et al., 1998; Ryerson et al., 1998, 2001; Sillman, 2000) examined the plume $\mathrm{NO}_{\mathrm{x}}$ chemical lifetime to evaluate the chemical evolution of power-plant plumes. On the other hand, Lawrence and Crutzen (1999) examined the chemical lifetimes of $\mathrm{NO}_{\mathrm{x}}$ emitted from ocean-going ships within the MBL, using an Eulerian 3-D photochemical model. However, the $\mathrm{NO}_{\mathrm{x}}$ chemical lifetimes were overestimated because their modeling study bypassed the nonlinear shipplume $\mathrm{NO}_{\mathrm{x}}$ chemistry. In order to include the nonlinear ship-plume chemistry, von Glasow et al. (2003) and Song et al. (2003a) used a Lagrangian photochemical box model to estimate the $\mathrm{NO}_{\mathrm{x}}$ chemical lifetimes more accurately. Their results clearly showed that the elevation of the plume $\mathrm{OH}$ concentrations reduces the $\mathrm{NO}_{\mathrm{x}}$ chemical lifetime by a factor of 2.5 3.0. Nevertheless, their study had some limitations in that: (i) the estimations were made only along the plume centerline, where it is difficult to represent the chemical evolution of the "entire volume" of the ship plume, and (ii) the model was used without adequate model verification. Here, the ship-plume $\mathrm{NO}_{\mathrm{x}}$ chemical lifetimes were examined again using the newly developed ship-plume photochemi$\mathrm{cal} /$ dynamic model, which can reflect the chemical aging of the entire ship-plume volume. The "instantaneous $\mathrm{NO}_{\mathrm{x}}$ lifetime $\left(\tau_{\mathrm{NO}_{\mathrm{x}}}^{i}\right)$ " defines how fast $\mathrm{NO}_{\mathrm{x}}$ is lost at a given point of time. $\tau_{\mathrm{NO}_{\mathrm{x}}}^{i}$ is defined as the $\mathrm{NO}_{\mathrm{x}}$ concentration at a given point of time divided by the rate of $\mathrm{NO}_{\mathrm{x}} \operatorname{loss}\left(L_{\mathrm{NO}_{\mathrm{x}}}^{i}\right)$ at a given time (Sillman, 2000; Song et al., 2003a; Chen et al.,
2005; Han et al., 2009):

$$
\begin{aligned}
& L_{\mathrm{NO}_{\mathrm{x}}}^{i}=k_{1}[\mathrm{OH}]\left[\mathrm{NO}_{2}\right]+k_{2}\left[\mathrm{NO}_{3}\right][\mathrm{DMS}] \\
& +k_{m t, \mathrm{NO}_{3}}\left[\mathrm{NO}_{3}\right]+2 k_{m t, \mathrm{~N}_{2} \mathrm{O}_{5}}\left[\mathrm{~N}_{2} \mathrm{O}_{5}\right] \\
& +k_{3}\left[\mathrm{CH}_{3} \mathrm{CO}_{3}\right]\left[\mathrm{NO}_{2}\right]-\left(k_{4}+J_{1}\right)[\mathrm{PAN}] \\
& \tau_{\mathrm{NO}_{\mathrm{x}}}^{i}=\frac{[\mathrm{NO}]+\left[\mathrm{NO}_{2}\right]}{L_{\mathrm{NO}_{\mathrm{x}}}^{i}}
\end{aligned}
$$

where $k_{1}, k_{2}, k_{3}$, and $k_{4}$ are the thermal reaction rate coefficients; $k_{m t, \mathrm{NO}_{3}}$ and $k_{m t, \mathrm{~N}_{2} \mathrm{O}_{5}}$ are the mass transfer coefficients $\left(\mathrm{s}^{-1}\right)$ for the heterogeneous conversion of atmospheric $\mathrm{NO}_{3}$ and $\mathrm{N}_{2} \mathrm{O}_{5}$ radicals, respectively (refer to Eqs. 1 and 2); and $J_{1}$ is the photo-dissociation rate coefficient of PAN.

A stable condition, as an example, was assumed in the estimations of $\tau_{\mathrm{NO}_{\mathrm{x}}}^{i}$. The estimated results are presented in Fig. 11. Panels $\mathrm{a}-\mathrm{h}$ in Fig. 11 correspond sequentially to plume transects $\mathrm{A}-\mathrm{H}$. Because the overall rate of $\mathrm{NO}_{\mathrm{x}}$ loss in Eq. (15) is controlled mainly by the $\mathrm{NO}_{2}+\mathrm{OH}$ reaction, the $\mathrm{OH}$ radical concentrations (dashed blue lines) tend to be inversely correlated with $\tau_{\mathrm{NO}_{\mathrm{x}}}^{i}$ (solid red lines) throughout the panels $\mathrm{a}-\mathrm{h}$ in Fig. 11. Highly non-linear and nonGaussian shape of the distribution in $\mathrm{OH}$ concentrations and $\tau_{\mathrm{NO}_{\mathrm{x}}}^{i}$ were observed at plume transects A to C. Such nonlinear chemistry occurs not only along the plume-advecting direction (i.e., $\mathrm{x}$-direction), but also across the plume crosssection (i.e., $y$ - and z-directions). This is one of the main reasons why the development of entire-volume ship-plume model is necessary. After the plume transects A to C, both the $\mathrm{OH}$ concentrations and $\tau_{\mathrm{NO}_{\mathrm{x}}}^{i}$ have Gaussian shapes across the plume cross-sections $(\mathrm{D}-\mathrm{H})$, with mirror-images of each other.

The averaged $\mathrm{OH}$ concentrations $([\overline{\mathrm{OH}}])$ and instantaneous $\tau_{\mathrm{NO}_{\mathrm{x}}}^{i}\left(\overline{\tau_{\mathrm{NO}_{\mathrm{x}}}^{i}}\right)$ across the plume cross-sections (A-H) 


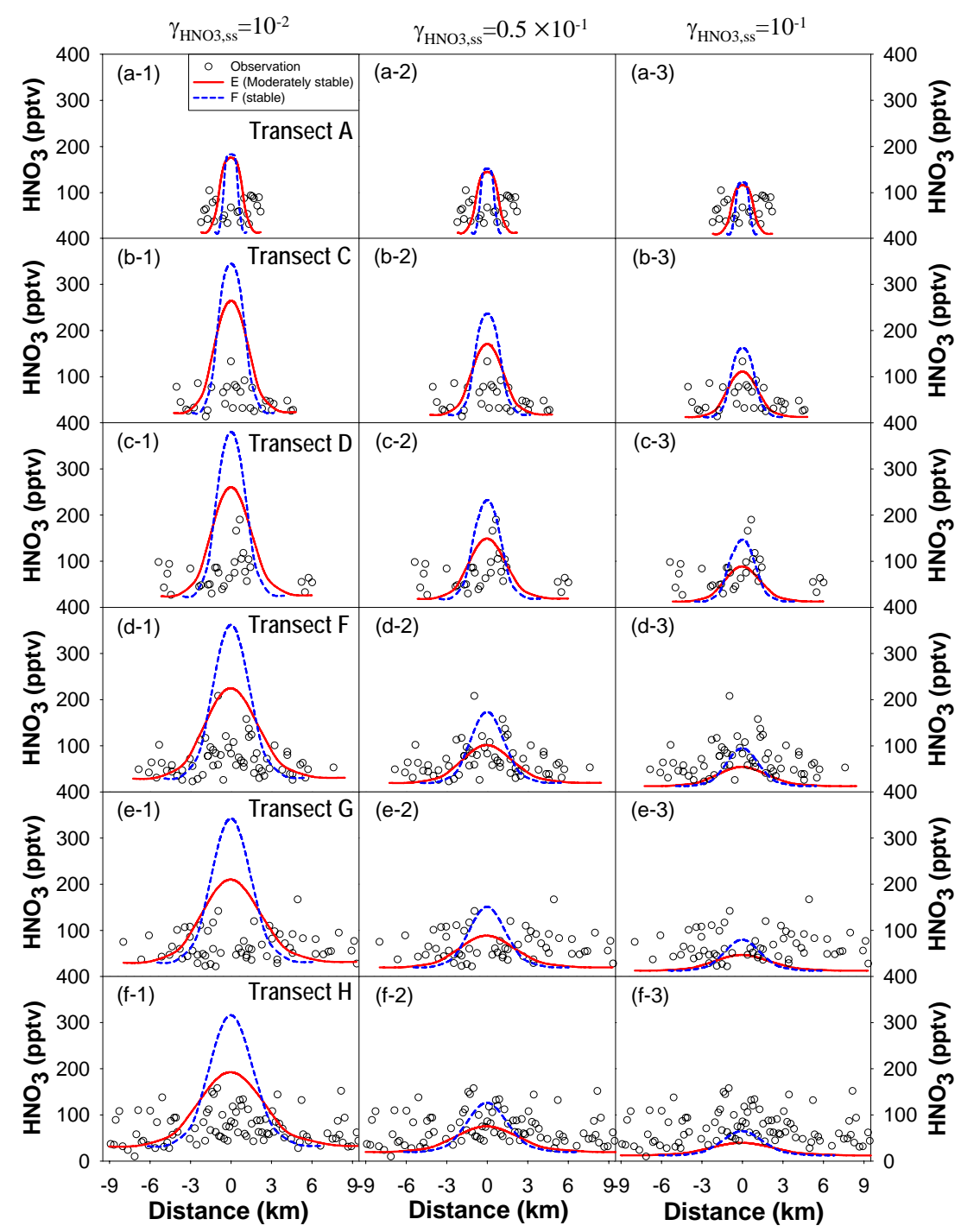

Fig. 10. Sensitivity tests for determining the reaction probability of $\mathrm{HNO}_{3}$ into sea-salt particles $\left(\gamma_{\mathrm{HNO}}\right.$, ss $)$. $\gamma_{\mathrm{HNO}}$, ss was relaxed from

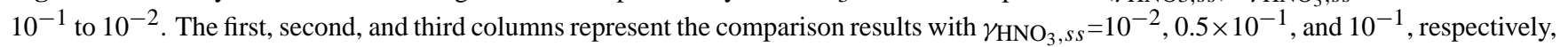
at transects $\mathrm{A}$ to $\mathrm{H}$.

are also shown inside the panels $\mathrm{a}-\mathrm{h}$ in Fig. 11. In particular, $\overline{\tau_{\mathrm{NO}_{\mathrm{x}}}^{i}}$ was calculated, considering the distribution of $\mathrm{NO}_{\mathrm{x}}$ concentrations, i.e.:

$w_{j}=\frac{\left.\mathrm{NO}_{\mathrm{x}}\right|_{j}}{\left.\sum_{j=1}^{n} \mathrm{NO}_{\mathrm{x}}\right|_{j}}$

$\overline{\tau_{\mathrm{NO}_{\mathrm{x}}}^{i}}=\left.\sum_{j=1}^{n} \tau_{\mathrm{NO}_{\mathrm{x}}}^{i}\right|_{j} w_{j}$

where $w_{j},\left.\mathrm{NO}_{\mathrm{x}}\right|_{j}$, and $\left.\tau_{\mathrm{NO}_{\mathrm{x}}}^{i}\right|_{j}$ represent the weight factor (or $\mathrm{NO}_{\mathrm{x}}$ fraction), $\mathrm{NO}_{\mathrm{x}}$ concentrations, and estimated instantaneous $\mathrm{NO}_{\mathrm{x}}$ lifetime $\left(\tau_{\mathrm{NO}_{\mathrm{x}}}^{i}\right)$ at the $j$-th bin of the $\mathrm{NO}_{\mathrm{x}}$ dis- tribution across a ship-plume cross-section, respectively. $n$ is the total number of bins of the $\mathrm{NO}_{\mathrm{x}}$ distribution across a ship-plume cross-section. The bins considered in this estimation ranged from $+3 \sigma$ to $-3 \sigma$. Figure 12 was drawn to show the changes in $[\overline{\mathrm{OH}}]$ and $\overline{\tau_{\mathrm{NO}_{\mathrm{x}}}^{i}}$ along the ship-plume travel distances under the moderately stable condition. Here, there is highly non-linear ship-plume photochemistry along the plume-advecting direction (i.e., in the $\mathrm{x}$-direction). The $[\overline{\mathrm{OH}}]$ and $\overline{\tau_{\mathrm{NO}_{\mathrm{x}}}^{i}}$ along the plume-advecting direction also have mirror-image distributions. The estimated $\overline{\tau_{\mathrm{NO}_{\mathrm{x}}}^{i}}$ ranges from 2.32 to $3.71(\mathrm{~h})$, and $\overline{\tau_{\mathrm{NO}_{\mathrm{x}}}^{i}}$ averaged over entire shipplume is $2.85(\mathrm{~h})$. In addition, [ $\overline{\mathrm{OH}}]$ ranges from $0.96 \times 10^{7}$ to $1.58 \times 10^{7}\left(\mathrm{~cm}^{-3}\right)$. Since the measured background $\mathrm{OH}$ 
radical concentrations were $0.61 \times 10^{7} \mathrm{~cm}^{-3}$, the ship-plume $\mathrm{OH}$ concentrations were elevated by factors of 1.6 to 2.6 as a result of the ship-plume chemistry. On the other hand, if $\overline{\tau_{\mathrm{NO}_{\mathrm{x}}}^{i}}$ is compared with the observed background $\mathrm{NO}_{\mathrm{x}}$ lifetime ( $\tau_{\mathrm{NO}_{\mathrm{x}}}^{b}$ ) of $\sim 6.5 \mathrm{~h}$ (Chen et al., 2005), it can be concluded that the nonlinear ship-plume chemistry shortens the $\mathrm{NO}_{\mathrm{x}}$ chemical lifetimes by a factor of $\sim 2.3$. The instantaneous $\mathrm{NO}_{\mathrm{x}}$ lifetime $\left(\overline{\tau_{\mathrm{NO}_{\mathrm{x}}}^{i}}\right)$ averaged over the plume crosssections were integrated further along the plume-advection direction (i.e., integration of $\overline{\tau_{\mathrm{NO}_{\mathrm{x}}}^{i}}$ along the red solid line shown in Fig. 12). This lifetime is called the "equivalent $\mathrm{NO}_{\mathrm{x}}$ lifetime $\left(\tau_{\mathrm{NO}_{\mathrm{x}}}^{e q}\right)$ ", which can be calculated using the following formula (Chen et al., 2005):

$\tau_{\mathrm{NO}_{\mathrm{x}}}^{e q}=\frac{\Delta t}{\int_{t}^{t+\Delta t} \overline{\tau_{\mathrm{NO}_{\mathrm{x}}}^{i}}}$

where $\Delta t$ denotes the estimation period of chemical evolution. The value of $\tau_{\mathrm{NO}_{\mathrm{x}}}^{e q}$ estimated by Eq. (19) from the plume transects $\mathrm{A}$ to $\mathrm{H}$ (i.e., $\Delta t=135 \mathrm{~min}$ ) is $2.64 \mathrm{~h} . \tau_{\mathrm{NO}_{\mathrm{x}}}^{e q}$ of $2.64 \mathrm{~h}$ is quite close to the simply averaged $\overline{\tau_{\mathrm{NO}_{\mathrm{x}}}^{i}}$ of $2.85 \mathrm{~h}$. $\tau_{\mathrm{NO}_{\mathrm{x}}}^{e q}$ was evaluated further from the location of the ship stack (i.e., travel distance $x=0$ ) to the approximate plume ending point (i.e., $x=180 \mathrm{~km}$ ). $\tau_{\mathrm{NO}_{\mathrm{x}}}^{e q}$ was estimated to be $\sim 3.25 \mathrm{~h}$ because the early plume development stage has a relatively longer $\mathrm{NO}_{\mathrm{x}}$ lifetime, due to the low levels of $\mathrm{OH}$.

However, the $\tau_{\mathrm{NO}_{\mathrm{x}}}^{e q}$ reported above was estimated for a case with a stable condition of the MBL. As mentioned previously, the most likely stability class for the ship case study would range from moderately stable (E) to stable (F) conditions. Furthermore, the most likely stability class in the ship-going remote MBL of the world oceans (i.e., the most common stability condition) would be neutral (D) (Song et al., 2003a). Therefore, an attempt was made to estimate $\tau_{\mathrm{NO}_{\mathrm{x}}}^{e q}$ with the three stability classes (neutral, moderately stable, and stable stability conditions) for the current ship case. $\tau_{\mathrm{NO}_{\mathrm{x}}}^{e q}$ tends to decrease as the MBL becomes more stable, i.e.: (1) $\tau_{\mathrm{NO}_{\mathrm{x}}}^{e q}=3.67 \mathrm{~h}$ at the neutral stability condition; (2) $\tau_{\mathrm{NO}_{\mathrm{x}}}^{e q}=2.86 \mathrm{~h}$ at the moderately stable stability condition; and (3) $\tau_{\mathrm{NO}_{\mathrm{x}}}^{e q}=2.64 \mathrm{~h}$ at the stable condition. Although $\tau_{\mathrm{NO}_{\mathrm{x}}}^{e q}$ of 2.64-3.67 h was estimated in this study, it cannot be generalized, because the $\tau_{\mathrm{NO}_{\mathrm{x}}}^{e q}$ values estimated were only for the specific ship case currently studied. Different locations, seasons, times, and ship conditions (such as emission rate) could yield different $\tau_{\mathrm{NO}_{\mathrm{x}}}^{e q}$ values.

Nevertheless, it would be still worthwhile to compare the $\tau_{\mathrm{NO}_{\mathrm{x}}}^{e q}$ estimated in this study with the $\tau_{\mathrm{NO}_{\mathrm{x}}}^{e q}$ from other studies. The lifetimes of 2.64-3.67 h are comparable yet rather smaller than that used by Beirle et al. (2004) $\left(\tau_{\mathrm{NO}_{\mathrm{x}}}^{e q}=3.70 \mathrm{~h}\right.$ at 10:30 a.m. LST, the GOME passing local time). Beirle et al.'s study (2004) targeted the ship plumes in the heavy ship traffic lanes at 10:30 LST between Sri Lanka and Malaysia

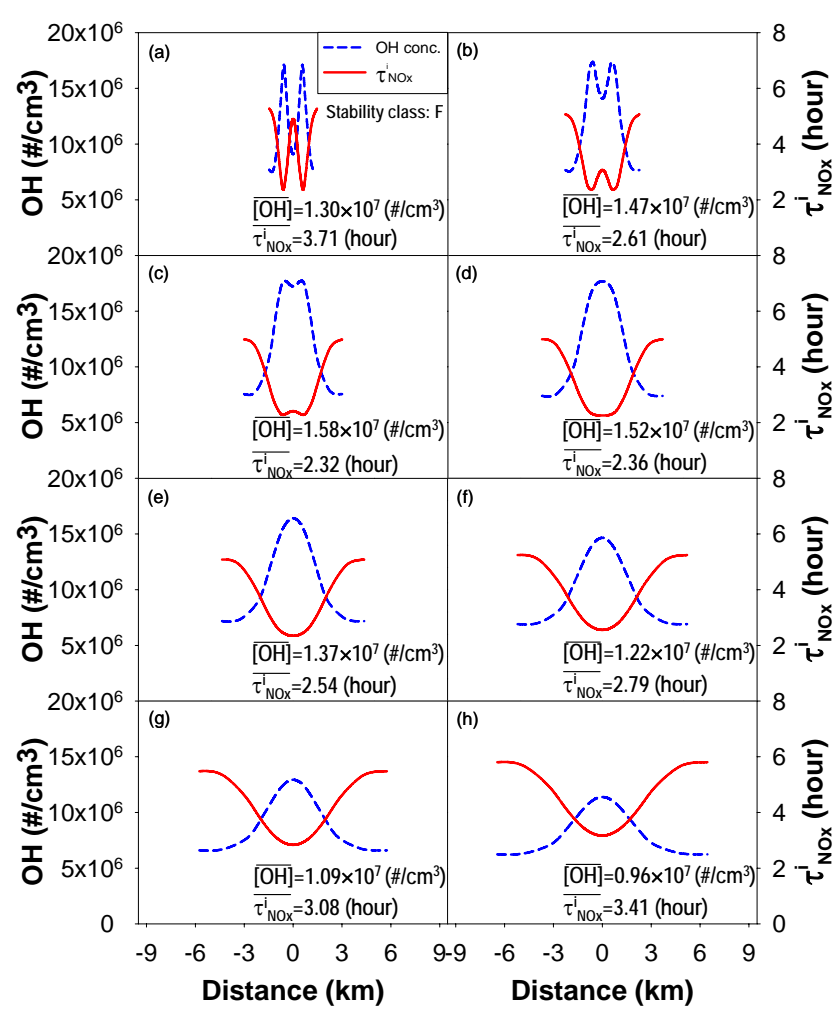

Fig. 11. $\mathrm{OH}$ radical concentrations and $\mathrm{NO}_{\mathrm{x}}$ lifetimes across the ship-plume transects $\mathrm{A}-\mathrm{H} .[\overline{\mathrm{OH}}]$ and $\left[\overline{\tau_{\mathrm{NO}_{\mathrm{x}}}^{i}}\right]$ represent the averaged $\mathrm{OH}$ concentration and instantaneous $\mathrm{NO}_{\mathrm{x}}$ lifetime over the ship-plume transects $\mathrm{A}-\mathrm{H}$, respectively. UBoM $2 \mathrm{~K} 8$ models were run at the stability condition of stable (F). The panels $(\mathbf{a}-\mathbf{h})$ correspond to the results at the ship-plume transects A-H, sequentially.

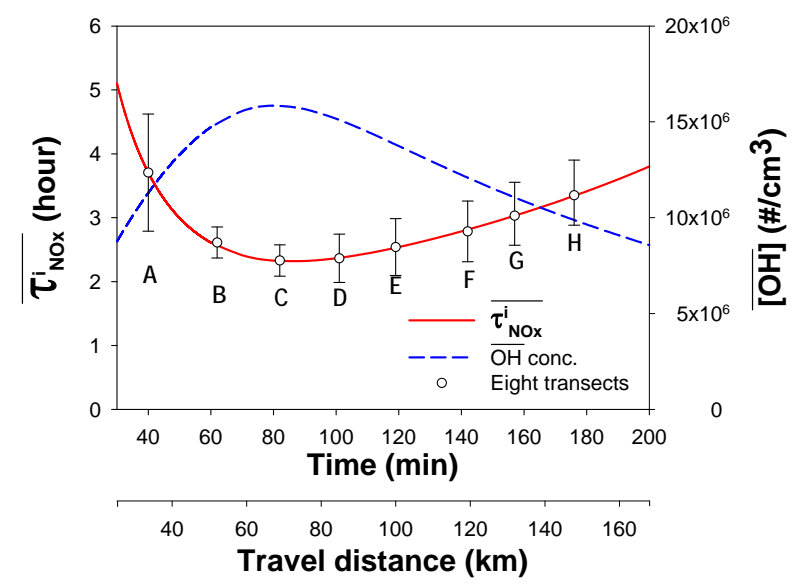

Fig. 12. Changes in $[\overline{\mathrm{OH}}]$ and $\left[\overline{\tau_{\mathrm{NO}_{\mathrm{x}}}^{i}}\right]$ along the ship-plume travel distances under the stability condition of stable (F). The bars represent the $\mathrm{OH}$ radical concentrations at $\pm \sigma$ in the eight ship-plume transects A-H. 
(i.e., different location, time, and season). Again, it should be emphasized that an accurate estimation of ship $\mathrm{NO}_{\mathrm{x}}$ lifetime is of primary importance, particularly regarding $\mathrm{NO}_{\mathrm{x}}$ emissions from ocean-going ships using satellite $\mathrm{NO}_{2}$ columns, as carried out by Beirle et al. (2004). In contrast, the $\mathrm{NO}_{\mathrm{x}}$ lifetimes inferred from this study are larger than those reported by Chen et al. (2005) $\left(\tau_{\mathrm{NO}_{\mathrm{x}}}^{e q}=1.81-2.38 \mathrm{~h}\right)$. This overestimation may be due partly to the fact that Chen et al. (2005) estimated $\tau_{\mathrm{NO}_{\mathrm{x}}}^{e q}$ only along the eight transects $\mathrm{A}$ to $\mathrm{H}$ because their modeling study was based on a photo-stationary state approximation. However, as indicated in Fig. 12, omitting the early ship-plume photochemical aging stages (particularly, between the ship location and transect A) can result in a smaller $\tau_{\mathrm{NO}_{\mathrm{x}}}^{e q}$ due to the low $\mathrm{OH}$ concentrations in the early ship-plume photochemical stages. In addition, as mentioned in $\mathrm{HNO}_{3}$ and $\mathrm{H}_{2} \mathrm{SO}_{4}$ analysis, there is another uncertainty in the model-predicted ship-plume $\mathrm{OH}$ radical concentrations that can affect $\tau_{\mathrm{NO}_{\mathrm{x}}}^{e q}$ significantly.

\section{Possible utility of the developed model: ship track study}

The developed photochemical/dynamic ship-plume model can be used to estimate $\tau_{\mathrm{NO}}^{e q}$ over the entire ship-plume volume. The photochemical/dynamic ship-plume model may also be valuable for understanding the effects of ship emissions on aerosol and cloud properties. For example, Russell et al. (1999) examined the effect of ship-emitted aerosols on the cloud properties in a "ship track" using both an aerosol microphysical model, which can consider condensational and coagulational growth, and a cloud microphysics model. In their study, the Monterey Area Ship Track (MAST) experiment data, which had been measured in almost the same area where the NOAA WP-3D aircraft observations were made, had been used. However, although their study employed detailed aerosol microphysical and cloud microphysics models, it was limited in that (1) the model study did not consider the highly non-linear ship plume chemistry, and (2) it did not account for the ship-plume dilution processes, and therefore the entrainment processes of the background air into the shipplume volume. However, such limitations can be overcome if the developed photochemical/dynamic ship-plume model is used. Therefore, it is expected that the combination of both detailed aerosol microphysical and cloud microphysics models with the ship-plume photochemical model shown in this study would allow more detailed ship track investigations in the future.

\section{General characteristics of ship-plume chemical evolution}

Sections 3 to 4 evaluated the performance of the newly developed ship-plume photochemical model, and examined the

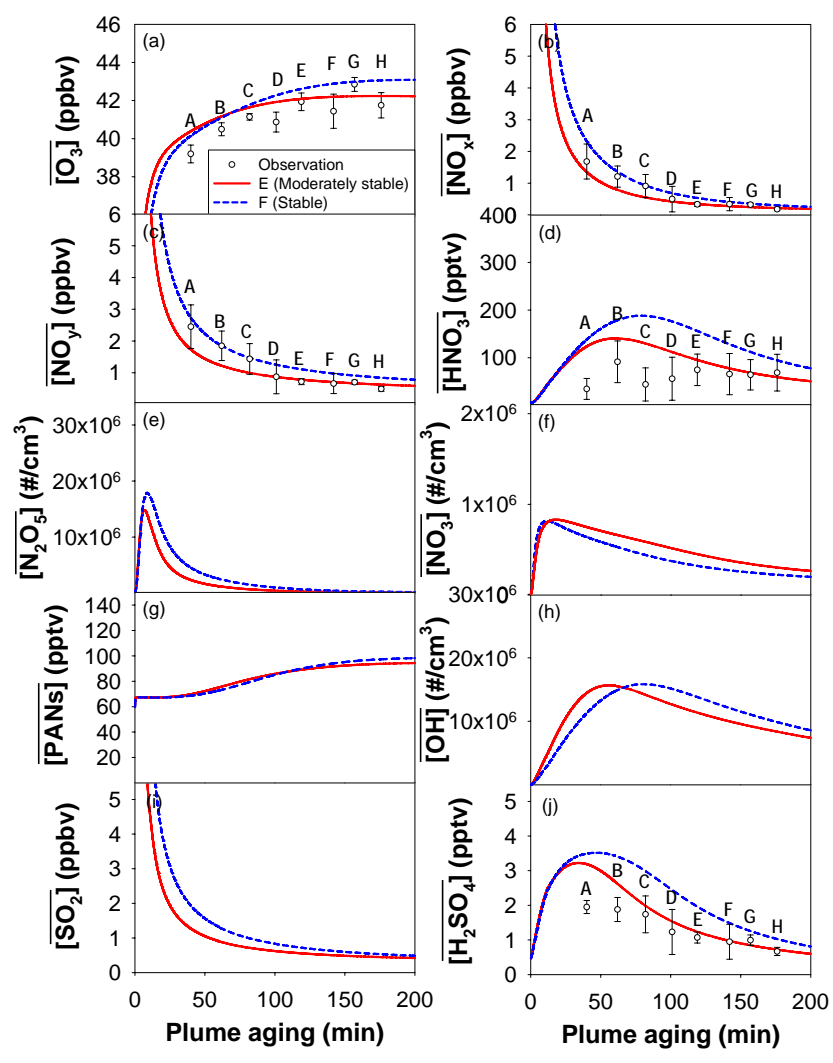

Fig. 13. Changes in ten major ship-plume species concentrations along the ship-plume travel times: (a) ozone; (b) $\mathrm{NO}_{\mathrm{x}}$; (c) $\mathrm{NO}_{\mathrm{y}}$; (d) $\mathrm{HNO}_{3}$; (e) $\mathrm{N}_{2} \mathrm{O}_{5}$; (f) $\mathrm{NO}_{3}$; (g) PANs; (h) $\mathrm{OH}$; (i) $\mathrm{SO}_{2}$; (j) $\mathrm{H}_{2} \mathrm{SO}_{4}$. The open circles and bars represent the observed average concentrations and concentrations at $\pm \sigma$, respectively. Here, the model runs were carried out with the stability class of moderately stable $(\mathrm{E})$ and stable $(\mathrm{F})$.

chemical evolution of ship plumes. However, the discussions were mainly of the measured five ship-plume species $\left(\mathrm{NO}_{\mathrm{x}}\right.$, $\mathrm{NO}_{\mathrm{y}}$, ozone, $\mathrm{HNO}_{3}$, and $\mathrm{H}_{2} \mathrm{SO}_{4}$ ) and the model-predicted $\mathrm{OH}$ radical concentrations. This section investigates the more general characteristics of the ship-plume chemical evolution. To do so, the ship-plume photochemical model was allowed to analyze the concentrations of ten major species. Figure 13 shows the changes in the concentrations of those species. Here, the open circles and bars represent the observed average concentrations and concentrations at $\pm \sigma$ at the eight transects, respectively. Both the solid and dashed lines represent the transect-averaged species concentrations calculated from the ship-plume model under moderately stable (E) and stable (F) conditions, respectively.

In Fig. 13b and i, as ship-plume develops, the concentrations of the primary pollutants, such as $\mathrm{NO}_{\mathrm{x}}$ and $\mathrm{SO}_{2}$, decrease almost exponentially due to dilution and chemical 
transformations. The changes in $\mathrm{NO}_{\mathrm{y}}$ tend to follow the trends of $\mathrm{NO}_{\mathrm{x}}$, as shown in panels $\mathrm{b}$ and $\mathrm{c}$, because the major constituent of $\mathrm{NO}_{\mathrm{y}}$ is $\mathrm{NO}_{\mathrm{x}}$. On the other hand, ozone is titrated due to the excessive levels of NO via Reaction (R2) during the early plume development stage, which is then recovered via Reactions (R3) and (R4) as the $\mathrm{NO}_{\mathrm{x}}$ concentration decreases. Figure 13a shows the dynamic and non-linear characteristics in the ship-plume ozone concentrations. Because the main source of $\mathrm{OH}$ radicals is ozone, the $\mathrm{OH}$ productions were also suppressed by the ozone titration. However, as ozone is recovered, the $\mathrm{OH}$ radical concentrations are also recovered via Reactions (R9) and (R10) as shown in Fig. 13h:

$\mathrm{O}_{3}+h v \rightarrow \mathrm{O}\left({ }^{1} \mathrm{D}\right)+\mathrm{O}_{2}$

$\mathrm{O}\left({ }^{1} \mathrm{D}\right)+\mathrm{H}_{2} \mathrm{O} \rightarrow 2 \mathrm{OH}$

When ozone depletion occurs, the $\mathrm{OH}$ concentrations also decrease to the very low levels. However, the $\mathrm{OH}$ concentration increases as the ozone is recovered, reaching a maximum level around local noontime. After that, its concentration decreases again. The hydroxyl radical $(\mathrm{OH})$ is the major oxidant in the atmosphere. Its atmospheric oxidation reactions produce two reservoir species in both the $\mathrm{N}$ - and $\mathrm{S}$ cycles: $\mathrm{HNO}_{3}$ and $\mathrm{H}_{2} \mathrm{SO}_{4}$. As mentioned previously, there are discrepancies between the observed and model-predicted $\mathrm{HNO}_{3}$ and $\mathrm{H}_{2} \mathrm{SO}_{4}$ concentrations in the young and relatively fresh ship plumes (positive biases are occurred). However, the differences between the model-predicted and observed $\mathrm{HNO}_{3}$ and $\mathrm{H}_{2} \mathrm{SO}_{4}$ concentrations become smaller in the photochemically-aged ship plumes. Since both the $\mathrm{HNO}_{3}$ and $\mathrm{H}_{2} \mathrm{SO}_{4}$ concentrations are controlled by the $\mathrm{OH}$ concentrations, their concentrations decrease after local noontime. Figure $13 \mathrm{e}$ and $\mathrm{f}$ shows the changes in the nighttime species, $\mathrm{N}_{2} \mathrm{O}_{5}$ and $\mathrm{NO}_{3}$. Although $\mathrm{N}_{2} \mathrm{O}_{5}$ and $\mathrm{NO}_{3}$ are nighttime species, the excessive $\mathrm{NO}_{2}$ concentrations increase the levels of these nighttime species to almost several pptv levels, even during the daytime. This type of phenomena was reported previously by Song et al. (2003a) in detail.

\section{Summary}

In this study, the photochemical/dynamic ship-plume model was developed to make a better understanding of the chemical evolution processes of a ship plume. In particular, to simulate the chemical evolution of the entire volume of the ship plume, the concentration distribution of the primary pollutants, such as $\mathrm{NO}_{\mathrm{x}}$ and $\mathrm{SO}_{2}$, were assumed to have Gaussian distributions. Being driven by the Gaussiandistributed primary pollutants, the newly developed photochemical/dynamic ship-plume model provides information on the chemical evolution of the ship-plume.

The simulation performance of the newly developed shipplume model was evaluated by a comparison with the data obtained from a ship-plume experiment carried out around local noon time on 8 May 2002 by the NOAA WP-3D aircraft. The model-simulation conditions were obtained directly and/or inferred indirectly from the NOAA WP-3D observations. In particular, the atmospheric stability conditions were estimated, analyzing the temperature profiles obtained from the WP-3D aircraft observations and NCEP reanalysis data. Based on the analysis, it was determined that the likely stability class within the MBL would be between the moderately stable (E) and stable (F) conditions. The primary pollutant concentrations, such as $\mathrm{NO}_{\mathrm{x}}$ and $\mathrm{SO}_{2}$, always showed higher values in the stable condition than in the moderately stable condition. In contrast, due to the nonlinear ship-plume chemistry, the concentrations of the secondary pollutants, such as ozone, $\mathrm{OH}$, and $\mathrm{NO}_{3}$, are higher in the moderately stable condition during the early ship-plume development stage. Comparison analysis of the observed and model-predicted ship-plume concentrations was carried out to analyze the model-simulation performances in more detail. The model-predicted concentrations of five ambient species $\left(\mathrm{NO}_{\mathrm{x}}, \mathrm{NO}_{\mathrm{y}}\right.$, ozone, $\mathrm{HNO}_{3}$, and $\left.\mathrm{H}_{2} \mathrm{SO}_{4}\right)$ showed good agreement with the observed concentrations at the eight plume transects by the WP-3D flight with strong correlations around the $1: 1$ line $(0.64 \leq R \leq 0.85)$.

The magnitude of the reaction probability of $\mathrm{HNO}_{3}$ onto sea-salt particles $\left(\gamma_{\mathrm{HNO}_{3}, s s}\right)$ was also investigated in the model-observation comparison framework. From the study, it was concluded that the magnitude of $\gamma_{\mathrm{HNO}_{3}, s s}$ might be in the order of $0.5 \times 10^{-1}-1.0 \times 10^{-1}$. In addition, the equivalent $\mathrm{NO}_{\mathrm{x}}$ lifetimes throughout the entire ship-plume were also estimated from ship-plume photochemical modeling. The chemical $\mathrm{NO}_{\mathrm{x}}$ lifetimes throughout the entire ship plume were estimated to be $2.64-3.76 \mathrm{~h}$ under stable (F) to neutral (D) stability conditions. This results clearly show that an increase in the levels of atmospheric oxidants in the ship plumes reduce the chemical lifetime of $\mathrm{NO}_{\mathrm{x}}$ within the MBL by a factor of $1.7 \sim 2.8$.

Acknowledgements. This work was funded by the Korea Meteorological Administration Research and Development Program under Grant CATER 2006-3201 in Korea. Authors thank David D. Parrish at NOAA (Aeronomy Laboratory) for his useful comments on the manuscript. We obtained all the ITCT $2 \mathrm{~K} 2$ airborne data sets from the official NOAA data archive at http://esrl.noaa.gov/csd/ tropchem/2002ITCT/P3/DataDownload/index.php.

Edited by: B. N. Duncan

\section{References}

Abbatt, J. P. D. and Waschewsky, G. C. G.: Heterogeneous interactions of $\mathrm{HOBr}, \mathrm{HNO}_{3}, \mathrm{O}_{3}$, and $\mathrm{NO}_{2}$ with deliquescent $\mathrm{NaCl}$ aerosols at room temperature, J. Phys. Chem. A, 102, 3719$3725,1998$. 
Atkinson, R., Baulch, D. L., Cox, R. A., Hampson Jr., R. F., Kerr, J. A., Rossi, M. J., and Troe, J.: Evaluated kinetic and photochemical data for atmospheric chemistry: Supplement V IUPAC Subcommittee on gas kinetic data evaluation for atmospheric chemistry, J. Phys. Chem. Ref. Data, 26, 215-280, 1997.

Beirle, S., Platt, U., von Glasow, R., Wenig, M., and Wanger, T.: Estimate of nitrogen oxide emissions from shipping by satellite remote sensing, Geophys. Res. Lett., 31, L18102, doi:10.1029/2004GL020312, 2004.

Brasseur, G. P., Orlando, J. J., and Tyndall, G. S.: Atmospheric Chemistry and Global Change, Oxford University Press, New York, 1999.

Brock, C. A., Hudson, P. K., Lovejoy, E. R., Sullivan A., Nowak, J. B., Huey, L. G., Cooper, O. R., Cziczo, D. J., de Gouw, J., Fehsenfeld. F. C., Holloway, J. S., Hübler, G., Lafleur, B. G., Murphy, D. M., Neuman, J. A., Nicks Jr., D. K., Orsini, D. A., Parrish, D. D., Ryerson, T. B., Tanner, D. J., Warneke, C., Weber, R. J., and Wilson, J. C.: Particle characteristics following cloud-modified transport from Asia to North America, J. Geophys. Res., 109, D23S26, doi:10.1029/2003JD004198, 2004.

Capaldo, K., Corbett, J. J., Kasibhatla, P., Fischbeck, P., and Pandis, S. N.: Effects of ship emissions on sulphur cycling and radiative climate forcing over the ocean, Nature, 400, 743-746. 1999.

Chen, G., Huey, L. G., Trainer, M., Nicks, D., Corbett, J., Ryerson, T., Parrish, D., Neuman, J. A., Nowak, J., Tanner, D., Holloway, J., Brock, C., Crawford, J., Olson, J. R., Sullivan, A., Weber, R., Schauffler, S., Donnelly, S., Atlas, E., Roberts, J., Flocke, F., Hübler, G., and Fehsenfeld, F.: An investigation of the chemistry of ship emission plumes during ITCT 2002, J. Geophys. Res., 110, D10S90, doi:10.1029/2004JD005236, 2005.

Corbett, J. J. and Fischbeck, P.: Emissions from ships, Science, 278, 823-824, 1997

Corbett, J. J., Fischbeck, P. S., and Pandis, S. N.: Global nitrogen and sulfur inventories for oceangoing ships, J. Geophys. Res., 104(D3), 3457-3470, 1999.

Corbett, J. J. and Koehler, H. W.: Updated emissions from ocean shipping, J. Geophys. Res., 108(D20), 4650, doi:10.1029/2003JD003751, 2003.

Crawford, J., Davis, D., Olson, J., Chen, G., Liu, S., Gregory, G., Barrick, J., Sachse, G., Sandholm, S., Heikes, B., Singh, H., and Blake, D.: Assessment of upper tropospheric $\mathrm{HO}_{\mathrm{x}}$ sources over the tropical pacific based on NASA GTE/PEM data: Net effect on $\mathrm{HO}_{\mathrm{x}}$ and other photochemical parameters, J. Geophys. Res., 104(D13), 16255-16273, 1999.

Davies, J. A. and Cox, R. A.: Kinetics of the heterogeneous reaction of $\mathrm{HNO}_{3}$ with $\mathrm{NaCl}$ : Effect of water vapor, J. Phys. Chem. A, 102, 7631-7642, 1998.

Davis, D. D., Grodzinsky, G., Kasibhatla, P., Crawford, J., Chen. G., Liu. S., Bandy, A., Thornton, D., Guan, H., and Sandholm, $\mathrm{S}$.: Impact of ship emissions on marine boundary layer $\mathrm{NO}_{\mathrm{x}}$ and $\mathrm{SO}_{2}$ distributions over the Pacific Basin, Geophys. Res. Lett., 28, 235-238, 2001.

DeMore, W. B., Sander, S. P., Golden, D. M., Hampson, R. F., Kurylo, M. J., Howard, C. J., Ravishankara, A. R., Kolb, C. E., and Molina, M. J.: Chemical kinetics and photochemical data for use in stratospheric modeling: Evaluation Number 12, JPL Publ., 97-4, 1997.

Endresen, Ø., Sørgård, E., Sundet, J. K., Dalsøren, S. B., Isaksen, I. S. A., Berglen, T. F., and Gravir, G.: Emission from international sea transportation and environmental impact, J. Geophys. Res., 108(D17), 4560, doi:10.1029/2002JD002898, 2003.

Fenter, F. F., Caloz, F., and Rossi, M. J.: Kinetics of nitric acid uptake by salt, J. Phys. Chem., 98, 9801-9810, 1994.

Ferek, R. J., Hegg, D. A., Hobbs, P. V., Durkee, P., and Nielsen, K.: Measurements of ship-induced tracks in clouds off the Washington coast, J. Geophys. Res., 103(D18), 23199-23206, 1998.

Freiberg, J. E. and Schwartz, S. E.: Oxidation of $\mathrm{SO}_{2}$ in aqueous droplets: Mass-transport limiation in laboratory studies and the ambient atmosphere, Atmos. Environ., 15, 1145-1154, 1981.

Ghosal, S. and Hemminger, J. C.: Surface adsorbed water on $\mathrm{NaCl}$ and its effect on nitric acid reactivity with $\mathrm{NaCl}$ powders, J. Phys. Chem. B, 108, 14102-14108, 2004.

Gill, A. E.: Atmosphere-Ocean Dynamics, Academic Press, 50-51, 1982.

Guimbaud, C., Arens, F., Gutzwiller, L., Gäggeler, H. W., and Ammann, M.: Uptake of $\mathrm{HNO}_{3}$ to deliquescent sea-salt particles: a study using the short-lived radioactive isotope tracer ${ }^{13} \mathrm{~N}$, Atmos. Chem. Phys., 2, 249-257, 2002, http://www.atmos-chem-phys.net/2/249/2002/.

Han, K. M., Song, C. H., Ahn, H. J., Park, R. S., Woo, J. H., Lee, C. K., Richter, A., Burrows, J. P., Kim, J. Y., and Hong, J. H.: Investigation of $\mathrm{NO}_{\mathrm{x}}$ emissions and $\mathrm{NO}_{\mathrm{X}}$-related chemistry in East Asia using CMAQ-predicted and GOME-derived $\mathrm{NO}_{2}$ columns, Atmos. Chem. Phys., 9, 1017-1036, 2009, http://www.atmos-chem-phys.net/9/1017/2009/.

Hanna, S. R., Schulman, L. L., Paine, R. J., Pleim, J. E., and Baer, M.: Development and evaluation of the offshore and coastal dispersion model, J. Air Pollut. Control Assoc., 35, 1039-1047, 1985.

Hewitt, C. N.: The atmospheric chemistry of sulphur and nitrogen in power station plumes, Atmos. Environ., 35, 1155-1170, 2001.

Hobbs, P. V., Garrett, T. J., Ferek, R. J., Strader, S. R., Hegg, D. A., Frick, G. M., Hoppel, W. A., Gasparovic, R. F., Russell, L. M., Johnson, D. W., O’Dowd, C., Durkee, P. A., Nielsen, K. E., and Innis, G.: Emissions from ships with respect to their effects on clouds, J. Atmos. Sci., 57, 2570-2590, 2000.

Holton, J. R.: An Introduction to Dynamic Meteorology, Academic Press, p. 53, 1992.

Hudson, J. G., Garrett, T. J., Hobbs, P. V., Strader, S. R., Xie, Y., and Yum, S. S.: Cloud condensation nuclei and ship tracks, J. Atmos. Sci., 57, 2696-2706, 2000

Huey, L. G. and Lovejoy, E. R.: Reactions of SiF5- with atmospheric trace gases: Ion chemistry for chemical ionization detection of $\mathrm{HNO}_{3}$ in the troposphere, Int. J. Mass Spectrom., 155, 133-140, 1996.

Jefferson, A., Eisele, F. L., Ziemann, P. J., Weber, R. J., Marti, J. J., and McMurry, P. H.: Measurements of the $\mathrm{H}_{2} \mathrm{SO}_{4}$ mass accommodation coefficient onto polydisperse aerosol, J. Geophys. Res., 102(D15), 19021-19028, 1997.

Karamchandani, P., Koo, A., and Seigneur, C.: Reduced gas-phase kinetic mechanism for atmospheric plume chemistry, Environ. Sci. Technol., 32, 1709-1720, 1998.

Karamchandani, P., Santos, L., Sykes, I., Zhang, Y., Tonne, C., and Seigneur, C.: Development and evaluation of a state-of-thescience reactive plume model, Environ. Sci. Technol., 34, 870880, 2000.

Kasibhatla, P., Levy II, H., Moxim, W. J., Pandis, S. N., Corbett, J. J., Peterson, M. C., Honrath, R. E., Frost, G. J., Knapp, K., 
Parrish, D. D., and Ryerson, T. B.: Do emissions from ship have a significant impact on concentrations of nitrogen oxides in the marine boundary layer?, Geophys. Res. Lett., 27, 2229-2232, 2000.

Laux, J. M., Hemminger, J. C., and Finlayson-Pitts, B. J.: X-ray photoelectron spectroscopic studies of the heterogeneous reaction of gaseous nitric acid with sodium chloride: Kinetics and contribution to the chemistry of the marine troposphere, Geophys. Res. Lett., 21, 1623-1626, 1994.

Lawrence, M. G. and Crutzen, P. J.: Influence of $\mathrm{NO}_{\mathrm{x}}$ emissions from ships on tropospheric photochemistry and climate, Nature, 402, 167-170, 1999.

Liu, Y., Cain, J. P., Wang, H., and Laskin, A.: Kinetic study of heterogeneous reaction of deliquesced $\mathrm{NaCl}$ particles with gaseous $\mathrm{HNO}_{3}$ using particle-on-substrate stagnation flow reactor approach, J. Phys. Chem. A, 111, 10026-10043, 2007.

Lurmann, F. W., Lloyd, A. C., and Atkinson, R.: A chemical mechanism for use in long-range transport/acid deposition computer modeling, J. Geophys. Res., 91(D10), 10905-10936, 1986.

Marbach, T., Beirle, S., Platt, U., Hoor, P., Wittrock, F., Richter, A., Vrekoussis, M., Grzegorski, M., Burrows, J. P., and Wagner, T.: Satellite measurements of formaldehyde from shipping emissions, Atmos. Chem. Phys. Discuss., 9, 10487-10511, 2009, http://www.atmos-chem-phys-discuss.net/9/10487/2009/.

Mari, C., Suhre, K., Rosset, R., Bates, T. S., Huebert, B. J., Bandy, A. R., Thornton, D. C., and Businger, S.: One-dimensional modeling of sulfur species during the First Aerosol Characterization Experiment (ACE 1) Lagrangian B, J. Geophys. Res., 104(D17), 21733-21749, 1999.

Neuman, J. A., Huey, L. G., Dissly, R. W., Fehsenfeld, F. C., Flocke, F., Holecek, J. C., Holloway, J. S., Hübler, G., Jakoubek, R., Nicks Jr., D. K., Parrish, D. D., Ryerson, T. B., Sueper, D. T., and Weinheimer, A. J.: Fast-response airborne in situ measurements of $\mathrm{HNO}_{3}$ during Texas 2002 Air Quality Study, J. Geophys. Res., 107(D20), 4436, doi:10.1029/2001JD001437, 2002.

Nowak, J. B., Parrish, D. D., Neuman, J. A., Holloway, J. S., Cooper, O. R., Ryerson, T. B., Nicks Jr., D. K., Flocke, F., Roberts, J. M., Atlas, E., de Gouw, J. A., Donnelly, S., Dunlea, E., Hübler, G., Huey, L. G., Schauffler, S., Tanner, D. J., Warneke, C., and Fehsenfeld, F. C.: Gas-phase chemical characteristics of Asian emission plumes observed during ITCT 2K2 over the eastern North Pacific Ocean, J. Geophys. Res., 109, D23S19, doi:10.1029/2003JD004488, 2004.

Orsini, D. A., Ma, Y., Sullivan, A., Sierau, B., Baumann, K., and Weber, R. J.: Refinements to the particle-into-liquid-sampler (PILS) for ground and airborne measurements of water soluble aerosol composition, Atmos. Environ., 37, 1243-1259, 2003.

Parrish, D. D., Kondo, Y., Cooper, O. R., Brock, C. A., Jaffe, D. A., Trainer, M., Ogawa, T., Hübler, G., and Fehsenfeld, F. C.: Intercontinental Transport and Chemical Transformation 2002 (ITCT 2K2) and Pacific Exploration of Asian Continental Emission (PEACE) experiments: An overview of the 2002 winter and spring intensives, J. Geophys. Res., 109, D23S01, doi:10.1029/2004JD004980, 2004.

Phinney, L., Leaitch, W. R., Lohmann, U., Shantz, N. C., and Worsnop, D. R.: Contributions from DMS and ship emissions to CCN observed over the summertime North Pacific, Atmos. Chem. Phys. Discuss., 9, 309-361, 2009,

http://www.atmos-chem-phys-discuss.net/9/309/2009/.
Radke, L. F., Coakley Jr., J. A., and King, M. D.: Direct and remote sensing observations of the effects of ships on clouds, Science, 246, 1146-1149, 1989.

Russell, L. M., Seinfeld, J. H., Flagan, R. C., Ferek, R. J., Hegg, D. A., Hobbs, P. V., Wobrock, W., Flossmann, A. I., O’Dowd, C. D., Nielsen, K. E., and Durkee, P. A.: Aerosol dynamics in ship tracks, J. Geophys. Res., 104(D24), 31077-31095, 1999.

Ryerson, T. B., Buhr, M. P., Frost, G. J., Goldan, P. D., Holloway, J. S., Hübler, G., Jobson, B. T., Kuster, W. C., McKeen, S. A., Parrish. D. D., Roberts, J. M., Sueper, D. T., Trainer, M., Williams, J., and Fehsenfeld, F. C.: Emissions lifetimes and ozone formation in power plant plumes, J. Geophys. Res., 130(D17), 2256922583, 1998

Ryerson, T. B., Trainer, M., Holloway, J. S., Parrish, D. D., Huey, L. G., Sueper, D. T., Frost, G. J., Donnelly, S. G., Schauffler, S, Atlas, E. L., Kuster, W. C., Goldan, P. D., Hübler, G., Meagher, J, F., and Fehenfeld, F. C.: Observation of ozone formation in power plant plumes and implications for ozone control strategies, Science, 292, 719-723, 2001.

Saul, T. D., Tolocka, M. P., and Johnston, M. V.: Reactive uptake of nitric acid onto sodium chloride aerosols across a wide range of relative humidities, J. Phys. Chem. A, 110, 7614-7620, 2006.

Seinfeld, J. H. and Pandis, S. N.: Atmospheric Chemistry and Physics: From Air Pollution to Climate Change, John Wiley and Sons, New York, 1998.

Sillman, S., Logan, J. A., and Wofsy, S. C.: A regional scale model for ozone in the United States with subgrid representation of urban and power plant plumes, J. Geophys. Res., 95(D5), 57315748, 1990.

Sillman, S.: Ozone production efficiency and loss of $\mathrm{NO}_{\mathrm{x}}$ in power plant plumes: Photochemical model and interpretation of measurements in Tennessee, J. Geophys. Res., 105(D7), 9189-9202, 2000.

Sinha, P., Hobbs, P. V., Yokelson, R. J., Christian, T. J., Kirchstetter, T. W., and Bruintjes, R.: Emissions of trace gases and particles from two ships in the southern Atlantic Ocean, Atmos. Environ., 37, 2139-2148, 2003.

Song, C. H. and Carmichael, G. R.: The aging process of naturallyemitted aerosol (sea-salt and marine aerosol) during long range transport, Atmos. Environ., 33, 2203-2218, 1999.

Song, C. H. and Carmichael, G. R.: Gas-particle partitioning of nitric acid modulated by alkaline aerosol, J. Atmos. Chem., 40, 1-22, 2001.

Song, C. H., Chen, G., Hanna, S. R., Crawford, J., and Davis, D. D.: Dispersion and chemical evolution of ship plumes in the marine boundary layer: Investigation of $\mathrm{O}_{3} / \mathrm{NO}_{\mathrm{y}} / \mathrm{HO}_{\mathrm{x}}$ chemistry, J. Geophys. Res., 108(D4), 4143, doi:10.1029/2002JD002216, 2003a.

Song, C. H., Chen, G., and Davis, D. D.: Chemical evolution and dispersion of ship plumes in the remote marine boundary layer: Investigation of sulfur chemistry, Atmos. Environ., 37, 26632679, 2003b.

Song, C. H., Maxell-Meier, K., Weber, R. J., Kapustin, V., and Clarke, A.: Dust composition and mixing state inferred from airborne composition measurements from ACE-Asia C130 Flight\#6, Atmos. Environ., 39, 359-369, 2005.

Song, C. H., Han, K. M., Cho, H. J., Kim, J., Carmichael, G. R., Kurata, G., Thongboonchoo, N., He, Z., and Kim, H. S.: A Lagrangian model investigation of chemico-microphysical evolu- 
tion of northeast Asian pollution plumes within the MBL during Trace-P, Atmos. Environ., 41, 8932-8951, 2007.

Talukdar, R. K., Gilles, M. K., Battin-Leclerc, F., Ravishankara, A. R., Fracheboud, J.-M., Orlando, J. J., and Tyndall, G. S.: Photolysis of ozone at $308 \mathrm{~nm}$ and $248 \mathrm{~nm}$ : Quantum yield of $\mathrm{O}\left({ }^{1} \mathrm{D}\right)$ as a function of temperature, Geophys. Res. Lett., 24, 1091-1094, 1997.

Tolocka, M. P., Saul, T. D., and Johnston, M. V.: Reactive uptake of nitric acid into aqueous sodium chloride droplets using realtime single-particle mass spectrometry, J. Phys. Chem. A, 108, 2659-2665, 2004.

Tuttle, K. L.: Combustion-generated emissions in marine propulsion systems, in Proceedings of the SNAME 1994 Environmental Symposium-Ship Design and Operation in Harmony with the Environment, Soc. of Nav. Archit. and Mar. Eng., Jersey City, NJ, 311-323, 1995.
Twomey, S.: The influence of pollution on shortwave albedo of clouds, J. Atmos. Sci., 34, 1149-1152, 1977.

von Glasow, R., Lawrence, M. G., Sander, R., and Crutzen, P. J.: Modeling the chemical effects of ship exhaust in the cloud-free marine boundary layer, Atmos. Chem. Phys., 3, 233-250, 2003, http://www.atmos-chem-phys.net/3/233/2003/.

Weber, R. J., Orsini, D., Daun, Y., Lee, Y.-N., Klotz, P. J., and Brechtel, F.: A particle-in-liquid collector for rapid measurement of aerosol bulk chemical composition, Aerosol Sci. Tech., 35, 718-727, 2001.

Worsnop, D. R., Zahniser, M. S., Kolb, C. E., Gardner, J. A., Watson, L. R., Van Doren, J. M., Jayne, J. T., and Davidovits, P.: Temperature dependence of mass accommodation of $\mathrm{SO}_{2}$ and $\mathrm{H}_{2} \mathrm{O}_{2}$ on aqueous surfaces, J. Phys. Chem., 93, 1159-1172, 1989. 